\title{
SEMIOTIKA POSITIONING POLITIK KANDIDAT DALAM VIDEO DEBAT KANDIDAT PILKADA JAKARTA 2017
}

\author{
Oleh: Iskandar, Sulvinajayanti, Nahrul Hayat \\ Sekolah Tinggi Agama Islam Negeri (STAIN) Parepare \\ Email: iskandar@stainparepare.ac.id
}

\begin{abstract}
;
This research is motivated by the rampant phenomenon of regional election campaign (Pilkada) through candidate debate which is broadcasted directly by television mass media. Candidate debate is a model of political communication that is fairly newly dipratekkan in the election of regional heads in Indonesia. Despite the public's attention, the candidate debate in the communication perspective has not been widely seen as the subject of communiqué research.

The research methodology used qualitative descriptive approach with semiotic analysis method. This approach is chosen because it is able to reveal various information by way of description in the form of verbal and nonverbal messages of a text in a special context that melatarinya. Data were collected through observation techniques, documentary studios and libraries as well as interviews of expert informants. The data were then analyzed using semiotics method developed by Roland Barthes consisting of two marking levels. The conclusion of the research results indicate that each candidate builds political positioning to form the image and the good impression in the mind of the audience. The comparison of the political positioning of the two candidate pairs is that Ahok-Djarot is a candidate for the regional head that is firm and straightforward, experienced, and secular with the nature of top-down policy making. While Anis-Sandi is a decent candidate for regional head and nurturing, pro people, and tend to be religious with the nature of decision making bottop-up.
\end{abstract}

Keyword : Semiotics, Political Positioning, Election Candidate Debate Jakarta. 


\section{Pendahuluan}

Jakarta adalah satu dari 101 dari provinsi dan kabupaten/kota yang menggelar pemilihan kepala daerah (Pilkada) serentak di tahun 2017. Sebagai ibu kota negara Jakarta menjadi barometer politik Indonesia. Proses politik yang akan selalu menarik perhatian masyarakat Indonesia. Hal ini disebabkan oleh setidaknya dua faktor utama yakni; Jakarta sebagai pusat otoritas politik nasional dan sebagai pusat konsentrasi media massa (centre of power and information). Dalam kalimat lain, Pilkada Jakarta adalah persaingan politik lokal yang berefek nasional.

Salah satu dimensi politik yang banyak menjadi diskursus publik (public discousre) adalah komunikasi politik. Selain bersifat praksis, komunikasi politik juga telah menjadi fenomena baru dalam khasanah akademik di tanah air khususnya bidang komunikasi. Komunikasi politik pada dasarnya tidak memiliki titik henti. Dia adalah nafas dari politik. Meski demikian, kulminasi komunikasi politik tabiatnya selalu memuncak di masa-masa pemilihan. Dimasa inilah persaingan politik sangat intens.

Persaingan politik itu sendiri meniscayakan adanya strategi komunikasi politik. Dalam setiap aktifitas komunikasi politik seperti debat publik atau debat kandidat, terdapat strategi pemasaran politik (political marketing) untuk memenangkan persaingan tersebut. ${ }^{1}$ Salah satu strategi dalam pemasaran politik adalah startegi Positioning politik. ${ }^{2}$

Positioning adalah istilah marketing yang didefenisikan sebagai segala aktifitas untuk menanamkan kesan di benak konsumen atau masyarakat agar mereka bisa membedakan produk dan jasa yang dihasilkan oleh organisasi yang bersangkutan. $^{3}$ Dalam konteks positioning politik, produk dan jasa yang dimaksudkan pengertian di atas dapat berupa pesan dan janji-janji politik, visi misi kandidat, ideologi partai politik, atau figur kandidat itu sendiri. Untuk

\footnotetext{
${ }^{1}$ Hafied Cangara, Komunikasi Politik, (Jakarta: PT. Raja Grafindo Persada, 2014), Edisi Revisi, 225- 234.

${ }^{2}$ Philip Kotler, and Eduardo L. Roberto.. Social Marketing; Strategies for Changing Public Behaviour, (New York: The Free Pass, 1989), hlm 54.

${ }^{3}$ A Ries \& Trout J, Positioning The Battle of Your Mind, (New York: McGraw-Hill, 1981), hlm. 5-7.
} 
menjadi dominan dalam benak masyarakat atau pemilih (voters), suatu produk politik harus ditanamkan dalam memori kolektif publik. Dan untuk menanamkan suatu produk politik, kandidat harus memastikan produk politik miliknya memiliki nilai pembeda (difference) dengan produk politik lainya. Positioning politik yang baik akan memudahkan pemilih untuk membedakan satu kandidat dengan kandidat lainya dan pada gilirannya akan membantu pemilih untuk memutuskan dukungannya.

Salah satu media kampanye yang populer pada masa kampanye Pilkada Jakarta 2017 adalah debat kandidat calon gubernur dan wakil gubernur Jakarta putaran ke-2 yang diselenggarakan oleh Komisi Pemilihan Umum (KPU). Debat ini disiarkan secara langsung (live) oleh beberapa media massa televisi nasional Indonesia. Setiap pasangan calon akan memaparkan visi misi program dan janji politik masing-masing dan disaksikan secara langsung tidak saja oleh warga Jakarta tetapi seluruh masyarakat Indonesia. Dalam debat ini pula kedua pasangan calon akan saling debat sesuai dengan aturan main yang diarahkan oleh moderator.

Sebagai salah satu media komunikasi dengan tujuan kampanye, debat kandidat melalui media televise telah menjadi bagian dari strategi pemenangan kandidat dalam PILKADA JAKARTA 2017. Menjadi media kampanye, tentu debat kandidat oleh kandidat diharapkan dapat menjadi pendongkrak popularitas, elektabilitas, dan lovalilitas kandidat di hati dan pikiran masyarakat. Dengan kata lain, debat kandidat pilkada Jakarta telah menjadi sarana pemasaran politik yang harus diperhatikan oleh setiap insan dan aktor politik di negeri ini. Sebagaimana yang telah diuraikan sebelumnya bahwa dalam pemasaran politik, hal utama yang perlu diperhatikan adalah positioning politik.

Debat kandidat kampanye PILKADA JAKARTA 2017 yang resmi (official) tentu tidak hadir dalam ruang hampa, melainkan hadir di tengah-tengah masyarakat beserta konteks sosial dan budaya yang melingkupinya. Pemaknaan secara intrinsik sebuah simbol tunggal dalam debat kandidat tidak akan lengkap tanpa memperhatikan unsur ekstrinsiknya. Adanya kedua unsur ini akan mempengaruhi keberagaman makna dalam mempersepsi setiap tanda yang ada. 
Hal ini memungkinkan positioning politik dari seorang kandidat kampanye dapat dikonstruksi.

Dengan demikian penelitian ini dimaksudkan untukmemahami apa makna dan bagamana konstruksi positiononing politik dalam debat Pilkada Jakarta 2017 putaran ke-2.

\section{Teori Retorika}

Bangsa Yunani kuno telah memiliki sinonim untuk istilah komunikasi yang dikenal dengan istilah "retorika". Aristoteles memandang retorika sebagai sesuatu yang secara inheren diresapi oleh semua orang. Bagi Aristoteles retorika adalah seni persuasi, suatu yang harus singkat, jelas dan meyakinkan, dengan keindahan bahasa yang disusun untuk hal-hal yang bersifat memperbaiki (corrective), memerintah (instructive), mendorong (suggestive) dan mempertahankan (defensive).

Menurut Junaisih S. Sunarjo, kata retorika berasal dari bahasa Yunani yakni "Rethor" yang berarti mahir berbicara.Secara istilah arti retorika menurut Corax adalah kecakapan berpidato di depan massa. Sedangkan bagi Plato retorikan adalah kefasihan berkata-kata untuk merebut jiwa massa.

Pengertian retorika juga dituliskan oleh Jalaluddin Rahmat. Menurut beliau, retorika adalah ilmu yang mempelajari cara mengatur komposisi kata-kata agar timbul kesan yang dikehendakinya pada diri khalayak. Pengertian ini menegaskan bahwa dalam praktik retorika ada intensi untuk mempengaruhi (influence) khalayak.Baik itu mempengaruhi pikiran, perasaan dan perilaku khalayak.

Dalam ilmu retorika dikenal konsep triadik tengtang ethos, pathos, dan $\operatorname{logos}\left(\right.$ West \& Turner, 2008). ${ }^{4}$ Ethos berkaitan dengan kredibilitas, pathos berkaitan denggan impresi emosional, dan logos yang mewakili impresi resional.Ketiga pilar retorika ini menjadi indikator dalam menganalisis sebuah pidato (public speaking).

\footnotetext{
${ }^{4}$ Richard West \& Lynn H. Turner, Pengantar Teori Komunika;Analisis dan Aplikasi, (Jakarta: Salemba Humanika,2008), Buku 2, h. 4-9.
} 
Adapun unsur-unsur retotika memiliki banyak kesamaan dengan unsur komunikasi.Sebagai teori awal dan teori klasik komunikasi, reotika yang diperkenalkan oleh Aristoteles, terdiri dari tiga unsur utama yakni pembicara (communicator), pesan (message), dan penerima (communicat).Hubungan ketiga unsur ini dapat dilihat pada gambar berikut.

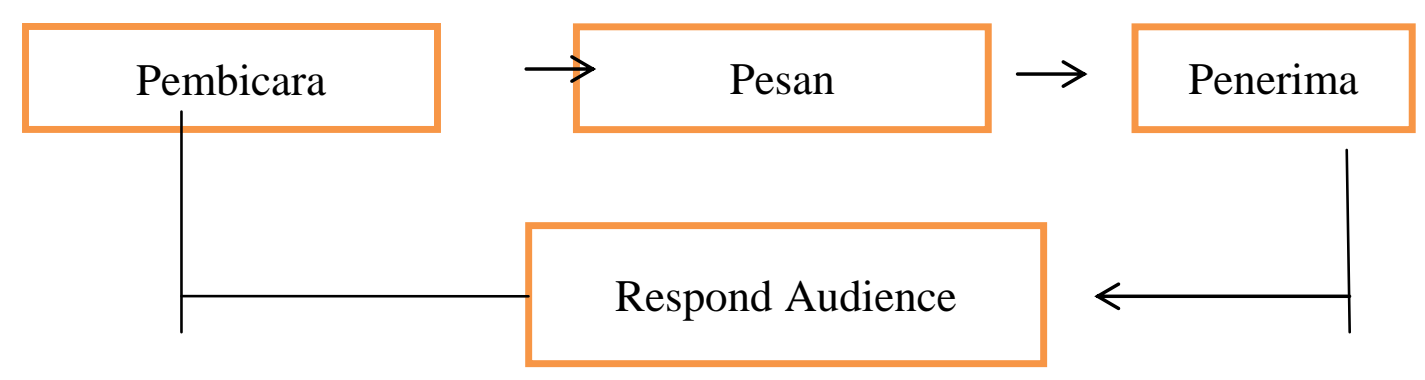

Gambar 1: Hubungan Unsur Retorika Aristoteles

\section{Pembahasan}

\section{Perbandingan Isu Politik; Visi-Misi dan Program Kandidat}

Keterangan Debat:

- Tema : Dari Masyarakat Untuk Jakarta

- Sub Tema : Transportasi, Pemukiman, Reklamasi, Pelayanan Publik dan

\section{UMKM}

- Moderator : Ira Koesno

- Tempat : Gedung Bidakara, Jakarta Selatan.

- Waktu : $20.00-22.00 \mathrm{WIB}$

- Hari/Tanggal : Rabu, 12 April 2017

- Komunitas : UMKM, Transportasi, Permukiman dan Rusun, Nelayan, dan Disabilitas

- Segmen Debat : 4 Segmen (Pertanyaan Panelis, komunitas, dan pertanyaan antarcalon) 
Tabel 1: Isu Politik Pasangan Calon

\begin{tabular}{|c|c|c|c|}
\hline \multirow[b]{2}{*}{ NO } & \multirow{2}{*}{$\begin{array}{c}\text { Nama } \\
\text { Pasangan } \\
\text { Calon }\end{array}$} & \multicolumn{2}{|c|}{ Isu Politik } \\
\hline & & Visi dan Misi & Program Kerja \\
\hline 1 & $\begin{array}{l}\text { Basuki } \\
\text { Tjahaja } \\
\text { Purnama - } \\
\text { Djarot Saiful } \\
\text { Hidayat } \\
\text { (Paslon No. } \\
\text { Urut 2) }\end{array}$ & $\begin{array}{l}\text { Visi: } \\
\text { Jakarta sebagai etalase kota } \\
\text { Indonesia yang modern, tertata } \\
\text { rapi, manusiawi, dan fokus } \\
\text { pada pembangunan manusia } \\
\text { seutuhnya dengan } \\
\text { kepemimpinan yang bersih, } \\
\text { transparan, dan profesional. } \\
\text { Misi: } \\
\text { 1. Mewujudkan pemerintahan } \\
\text { yang bebas korupsi, kolusi, } \\
\text { dan nepotisme (KKN), } \\
\text { terbuka, dan melayani } \\
\text { warga. } \\
\text { 2. Menjamin terpenuhinya } \\
\text { kebutuhan dasar warga, } \\
\text { yaitu jaminan kesehatan, } \\
\text { jaminan pendidikan, hunian } \\
\text { yang layak, bahan pangan } \\
\text { yang terjangkau, } \\
\text { transportasi publik yang } \\
\text { ekonomis, dan lapangan } \\
\text { bekerjaan serta usaha agar } \\
\text { seluruh warga }\end{array}$ & $\begin{array}{l}\text { Kesehatan } \\
\text { 1. Puskesmas menjadi } \\
\text { garda terdepan } \\
\text { pencegahan penyakit } \\
\text { bagi warga. } \\
\text { 2. membangun sanitasi } \\
\text { yang baik melalui } \\
\text { program bedah rumah. } \\
\text { Mengefektifkan PKK } \\
\text { dan Dasawisma untuk } \\
\text { memberikan penyuluhan } \\
\text { dan penerangan kepada } \\
\text { masyarakat yang rentan } \\
\text { terhadap penyakit } \\
\text { menular. } \\
\text { 3. Membangun Ruang } \\
\text { Terbuka Ramah Anak di } \\
\text { setiap wilayah. }\end{array}$ \\
\hline
\end{tabular}




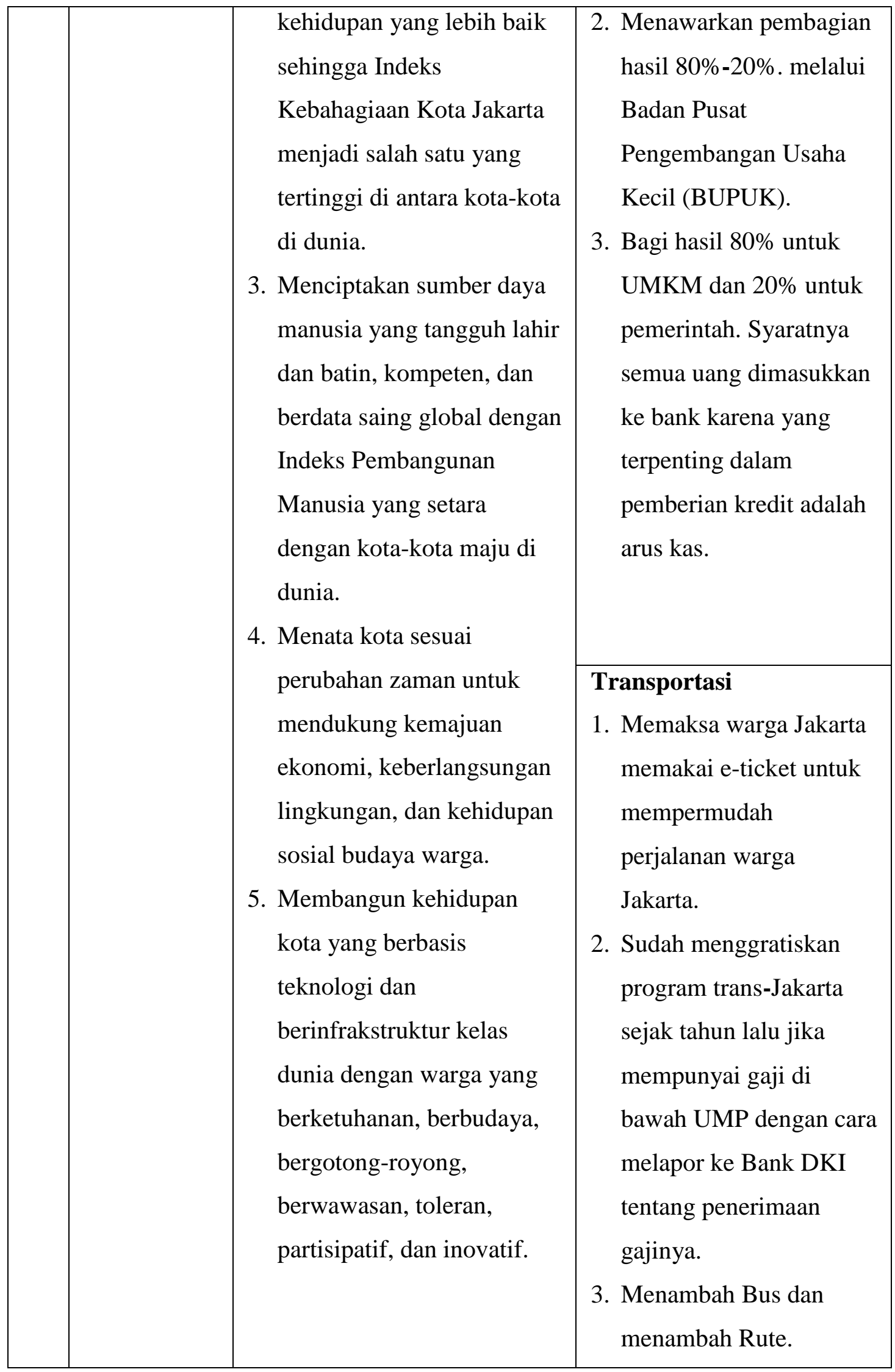




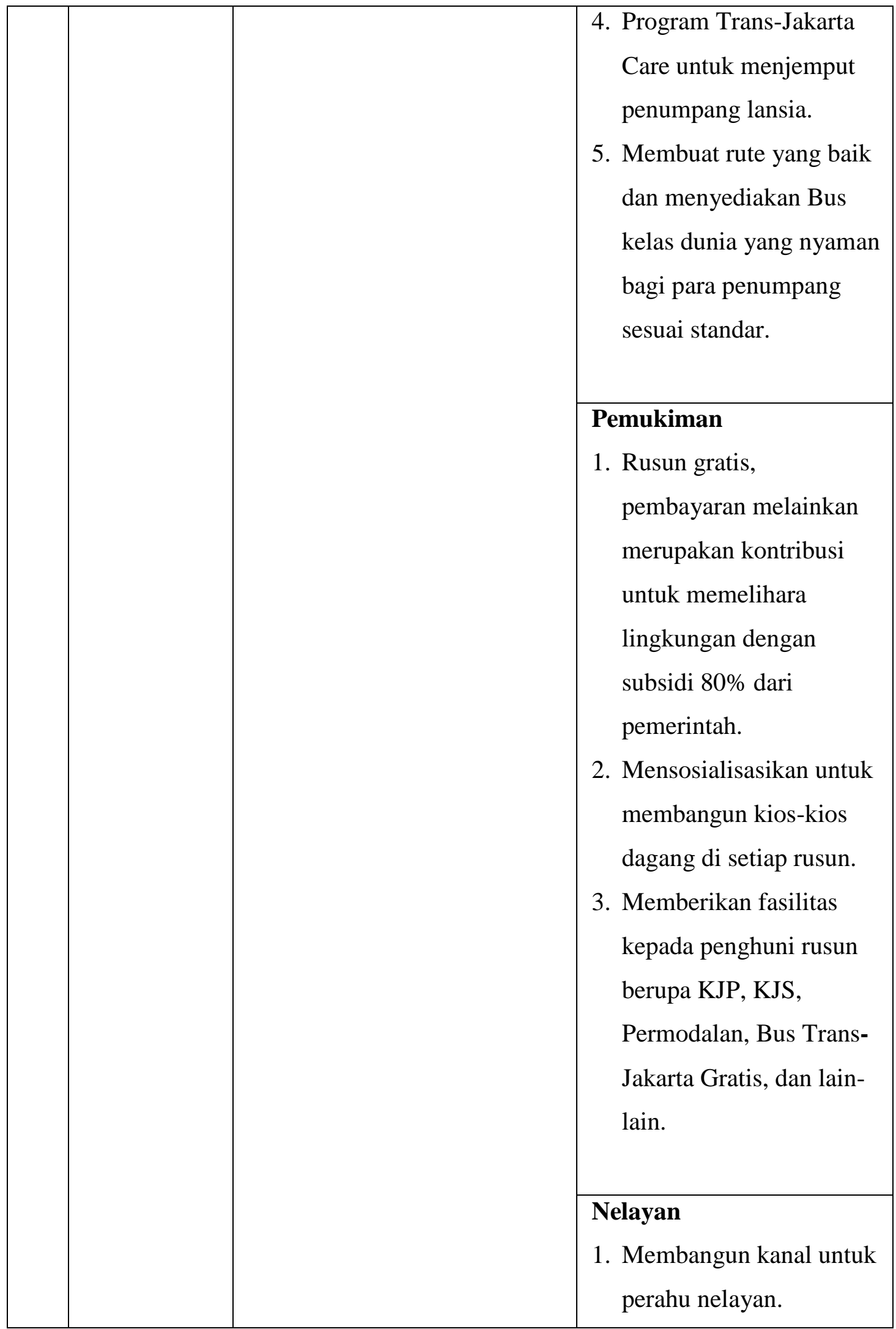




\begin{tabular}{|c|c|c|c|}
\hline & & & $\begin{array}{l}\text { 2. Menambah tanah } 10 \\
\text { Hektar di Rusun Muara } \\
\text { Baru yang berfungsi } \\
\text { sebagai tempat kapal } \\
\text { bersandar sekaligus } \\
\text { tempat penyimpanan } \\
\text { ikan dan pengolahan } \\
\text { ikan yang akan dimiliki } \\
\text { oleh nelayan. } \\
\text { 3. Menyiapkan rumah } \\
\text { susun Muara Angke dan } \\
\text { membuat sejumlah } \\
\text { tanggul serta restoran } \\
\text { apung bagi para ibu-ibu } \\
\text { nelayan. } \\
\text { 4. Membangun TPI } \\
\text { (Tempat Pelelangan } \\
\text { Ikan) yang memadai. } \\
\text { 5. Menata rumah-rumah } \\
\text { nelayan di wilayah } \\
\text { pantai Jakarta. }\end{array}$ \\
\hline 2 & $\begin{array}{l}\text { Anies Rasyid } \\
\text { Baswedan - } \\
\text { Sandiaga } \\
\text { Salahuddin } \\
\text { Uno (Paslon } \\
\text { No. Urut 3) }\end{array}$ & $\begin{array}{l}\text { Visi: } \\
\text { Jakarta kota maju dan beradab } \\
\text { dengan seluruh warga } \\
\text { merasakan keadilan dan } \\
\text { kesejahteraan. } \\
\text { Misi: } \\
\text { 1. Membangun manusia } \\
\text { Jakarta menjadi warga yang }\end{array}$ & $\begin{array}{l}\text { Kesehatan } \\
\text { 1. Fokus pada kesehatan } \\
\text { warga dan kesehatan } \\
\text { lingkungan. } \\
\text { 2. Merekrut tenaga-tenaga } \\
\text { medis yang akan } \\
\text { berkeliling di kampung- } \\
\text { kampung memastikan } \\
\text { bukan saja keluarga }\end{array}$ \\
\hline
\end{tabular}


Iskandar dkk, Semiotika Positioning Politik Kandidat ...

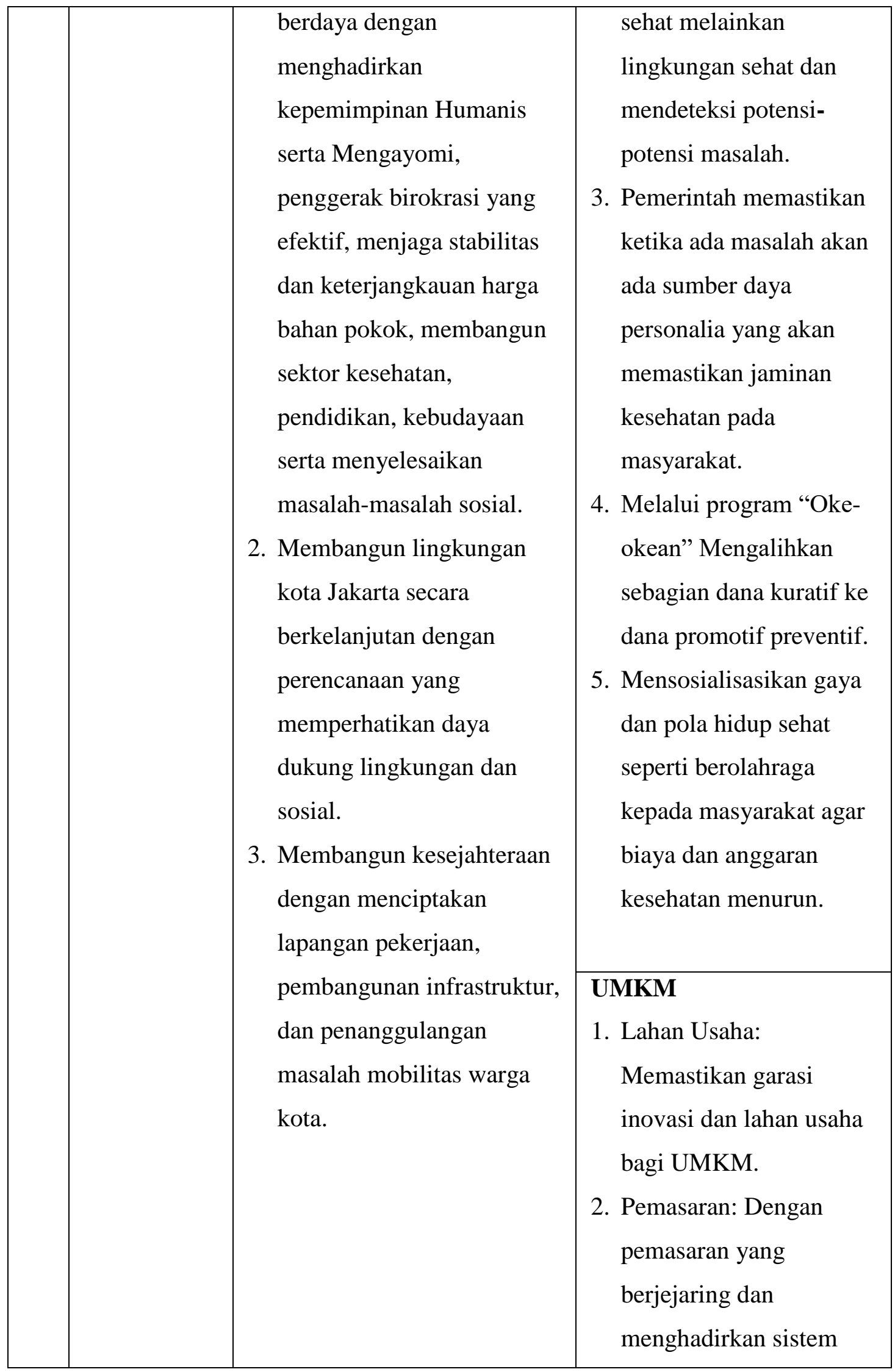




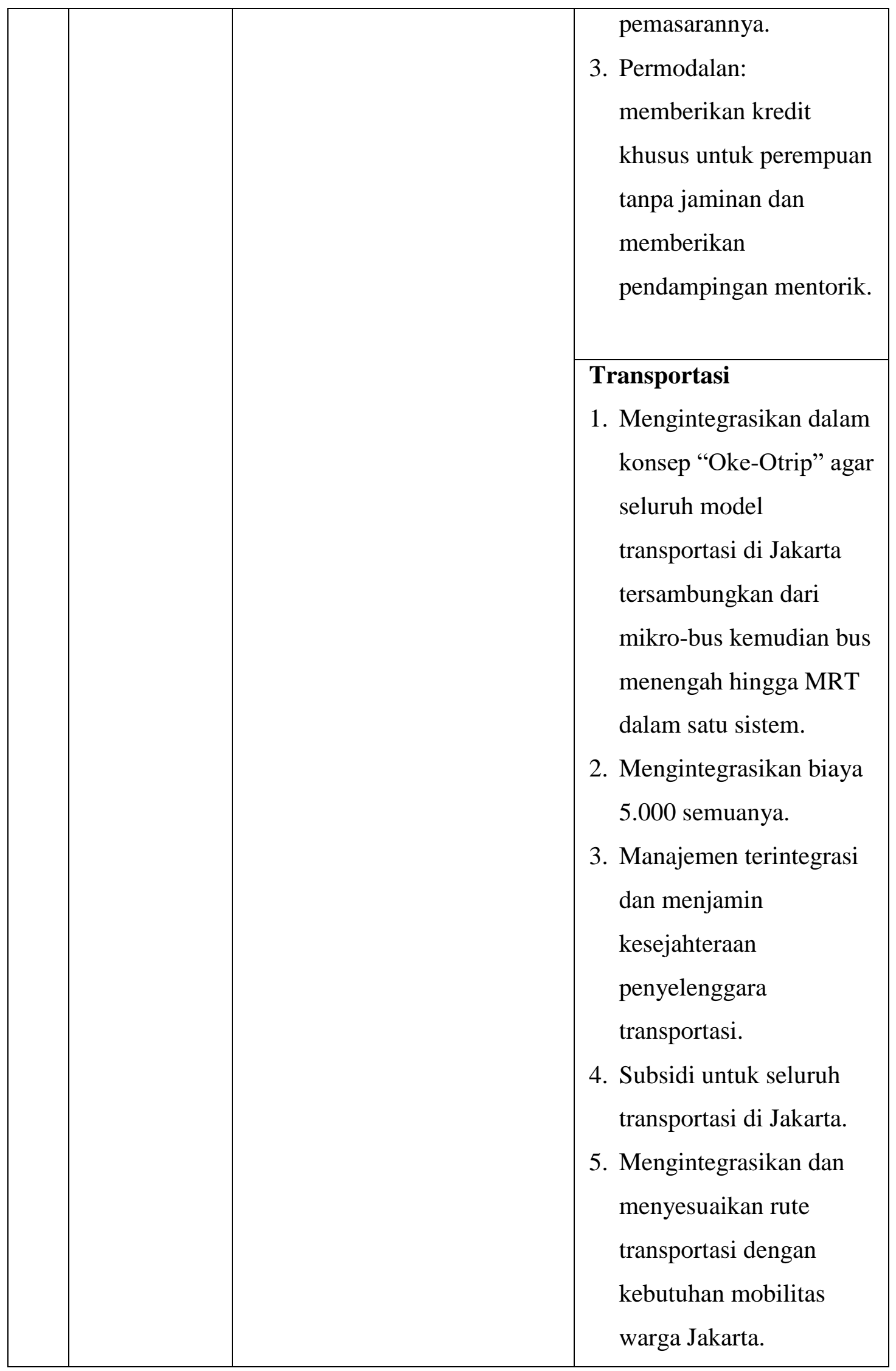




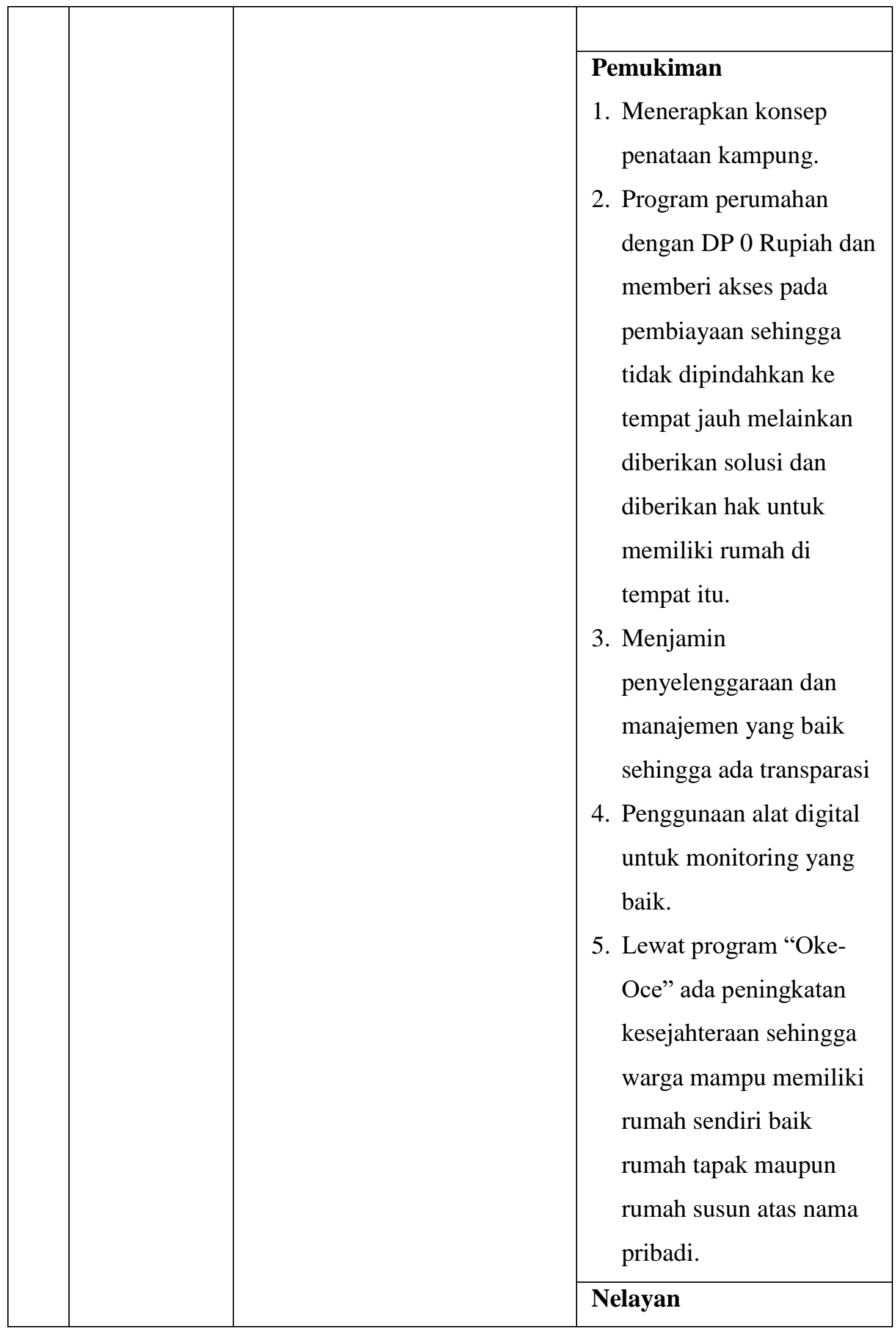




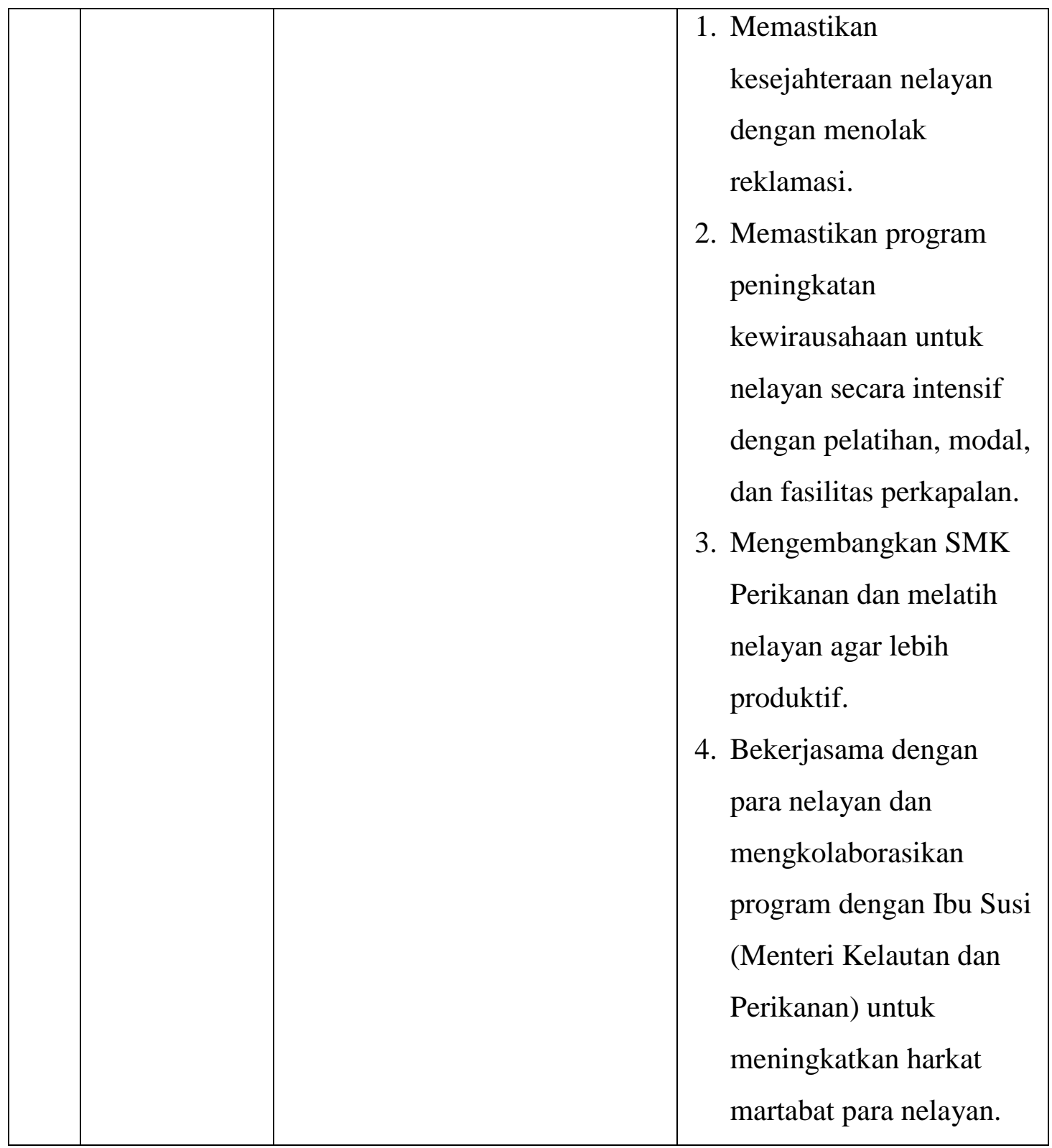

Analisis Makna SemiotisDebat Pilkada DKI Jakarta 2017

Tabel 2: Tanda Denotatif Debat Pilkada Jakarta 2017

\begin{tabular}{|l|c|c|l|}
\hline NO & Nama Kandidat & \multicolumn{2}{|c|}{ Tanda Denotatif } \\
\cline { 3 - 4 } & & \multicolumn{1}{|c|}{ Vebal } & \multicolumn{1}{|c|}{ Non-Verbal } \\
\hline 1. & \multirow{2}{*}{ Basuki Tjahaja Purnama } & 1. Memaparkan program & Penampilan \\
& kerja secara lugas, & Kemeja khas bermotif \\
(Cagub Paslon no. urut 2) & kalimat padat dan & kotak-kotak dengan \\
\hline
\end{tabular}




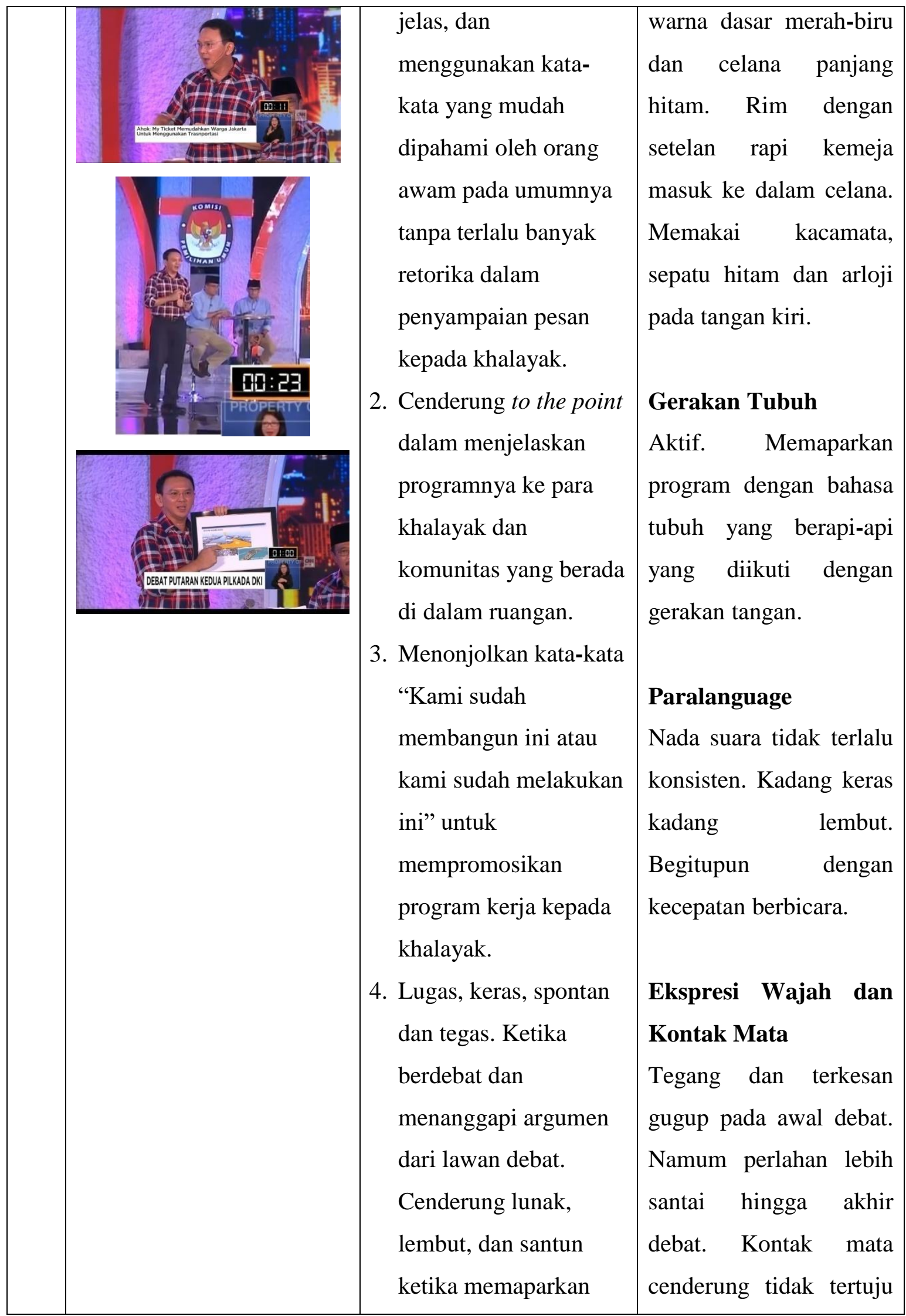




\begin{tabular}{|c|c|c|c|}
\hline & & $\begin{array}{l}\text { program kerja kepada } \\
\text { khalayak. }\end{array}$ & $\begin{array}{l}\text { pada lawan debat baik } \\
\text { ketika mendengarkan } \\
\text { maupun } \\
\text { memaparkan. }\end{array}$ \\
\hline 2. & $\begin{array}{c}\text { Djarot Saiful Hidayat } \\
\text { (Cawagub Paslon no. urut } \\
\text { 2) }\end{array}$ & $\begin{array}{l}\text { 1. Memaparkan program } \\
\text { kerja secara padat dan } \\
\text { jelas. Menggunakan } \\
\text { kata-kata yang bersifat } \\
\text { halus seperti } \\
\text { “melayani dengan } \\
\text { hati” untuk menarik } \\
\text { simpati khalayak. } \\
\text { 2. Menjadi penyeimbang } \\
\text { sebagai pasangan } \\
\text { Basuki dengan } \\
\text { menggunakan kata- } \\
\text { kata yang sopan, } \\
\text { santun, bertata krama, } \\
\text { dan bersifat ke-bapak- } \\
\text { an. } \\
\text { 3. Menonjolkan kata-kata } \\
\text { “Kami sudah } \\
\text { membangun ini atau } \\
\text { kami sudah melakukan } \\
\text { ini” untuk } \\
\text { mempromosikan } \\
\text { program kerja kepada } \\
\text { khalayak. } \\
\text { 4idak tegas dalam }\end{array}$ & $\begin{array}{l}\text { Penampilan } \\
\text { Kemeja khas bermotif } \\
\text { kotak-kotak dengan } \\
\text { warna dasar merah-biru } \\
\text { dan celana panjang } \\
\text { hitam. Rim dengan } \\
\text { setelan rapi kemeja } \\
\text { masuk ke dalam celana. } \\
\text { Memakai kacamata, } \\
\text { sepatu hitam dan peci } \\
\text { hitam. } \\
\text { Gerakan Tubuh } \\
\text { Menggunakan gerakan } \\
\text { tangan yang cenderung } \\
\text { sama ketikamenjelaskan } \\
\text { program kerja. Tenang } \\
\text { dan agak kaku di tempat. } \\
\text { Intonasi suara yang } \\
\text { lembut, perlahan, santun } \\
\text { kan mencitrakan sifat } \\
\text { Maralanguage }\end{array}$ \\
\hline
\end{tabular}




\begin{tabular}{|c|c|c|c|}
\hline & & $\begin{array}{l}\text { menyampaikan } \\
\text { program. Banyaknya } \\
\text { penggunakan bahasa } \\
\text { yang salah seperti } \\
\text { tidak terdengar jelas } \\
\text { atau kehilangan satu } \\
\text { kata sehingga } \\
\text { khalayak, dalam hal } \\
\text { ini beberapa peserta } \\
\text { FGD tidak memahami } \\
\text { salah satu dari } \\
\text { argumen yang } \\
\text { dipaparkan. }\end{array}$ & $\begin{array}{l}\text { Ekspresi Wajah dan } \\
\text { Kontak Mata } \\
\text { Menampilkan ekspresi } \\
\text { wajah yang cenderung } \\
\text { datar namun diselingi } \\
\text { dengan senyuman } \\
\text { hangat. Kontak mata } \\
\text { lebih banyak tertuju } \\
\text { kepada lawan debat } \\
\text { dibandingkan kepada } \\
\text { khalayak. }\end{array}$ \\
\hline 3. & $\begin{array}{l}\text { Anies Rasyid Baswedan } \\
\text { (Cagub Paslon no. urut 3) }\end{array}$ & $\begin{array}{l}\text { 1. Menggunakan bahasa } \\
\text { dan kata yang } \\
\text { umumnya mudah } \\
\text { dipahami oleh seluruh } \\
\text { kalangan. Meski } \\
\text { terkadang ada } \\
\text { beberapa kata ilmiah } \\
\text { dan analogi yang sulit } \\
\text { dicerna oleh khalayak. } \\
\text { 2. Menggunakan bahasa } \\
\text { yang ramah, sopan, } \\
\text { santun, bertata krama, } \\
\text { dan menampilkan nilai } \\
\text { adat ketimuran. } \\
\text { 3. Cenderung } \\
\text { menggunakan teknik } \\
\text { retorika tinggi dengan } \\
\text { pemakaian majas }\end{array}$ & 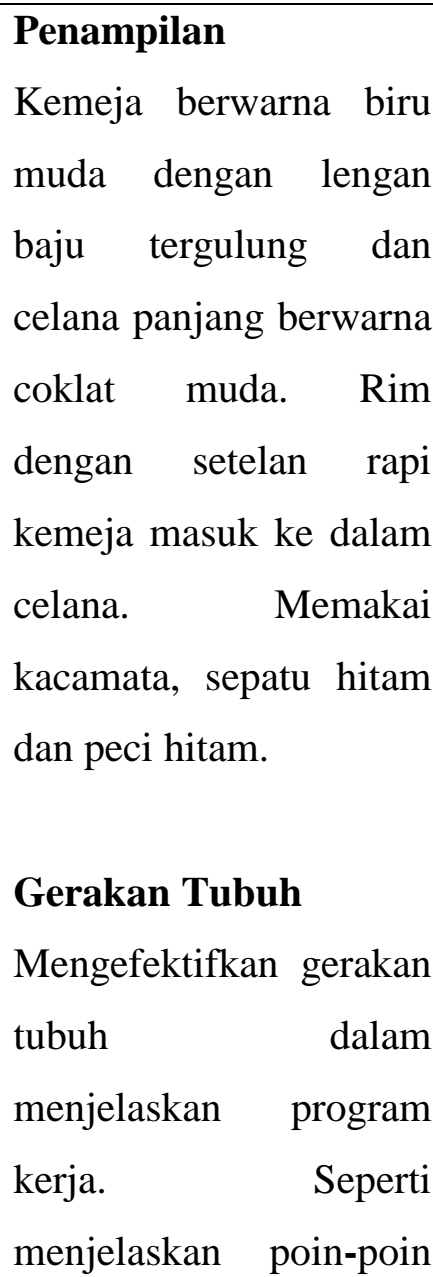 \\
\hline
\end{tabular}


Iskandar dkk, Semiotika Positioning Politik Kandidat ...

\begin{tabular}{|c|c|c|c|}
\hline & & $\begin{array}{l}\text { ketika menyampaikan } \\
\text { program kerja untuk } \\
\text { menarik simpati para } \\
\text { khalayak. } \\
\text { Menggunakan kata- } \\
\text { kata yang sopan untuk } \\
\text { mengkritik program } \\
\text { lawan debatnya. } \\
\text { Meskipun bahasanya } \\
\text { santun namun tetap } \\
\text { memberikan tekanan } \\
\text { kepada lawan } \\
\text { debatnya. }\end{array}$ & $\begin{array}{l}\text { program menggunakan } \\
\text { gerakan tangan dan jari. } \\
\text { Paralanguage } \\
\text { Intonasi suara yang } \\
\text { tenang dan tidak terlalu } \\
\text { cepat. Artikulasi jelas } \\
\text { dengan ritme terjaga. } \\
\text { Ekspresi Wajah dan } \\
\text { Kontak Mata } \\
\text { Kadang menampilkan } \\
\text { ekspresi cemberut dan } \\
\text { menunduk ketika } \\
\text { mendengarkan lawan } \\
\text { debat. Kontak mata } \\
\text { lebih banyak tertuju ke } \\
\text { khalayak. }\end{array}$ \\
\hline 4. & $\begin{array}{c}\text { Sandiaga Salahuddin Uno } \\
\text { (Cawagub Paslon no. Urut } \\
\text { 3). }\end{array}$ & $\begin{array}{l}\text { 1. Menggunakan bahasa } \\
\text { yang sopan, santun, } \\
\text { dan kadang } \\
\text { bercandaketika beradu } \\
\text { argumen dengan lawan } \\
\text { debat. } \\
\text { 2. Memaparkan program } \\
\text { kerja dengan singkat, } \\
\text { padat, dan jelas tanpa } \\
\text { menggunakan retorika } \\
\text { yang terlalu tinggi. } \\
\text { 3. Memaparkan program } \\
\text { kerja selayaknya } \\
\text { seorang pengusaha }\end{array}$ & $\begin{array}{l}\text { Penampilan } \\
\text { Kemeja berwarna biru } \\
\text { muda dengan lengan } \\
\text { baju tergulung dan } \\
\text { celana panjang berwarna } \\
\text { coklat muda. Kemeja } \\
\text { tidak masuk ke dalam } \\
\text { celana. Memakai } \\
\text { kacamata, arloji di } \\
\text { tangan kiri, sepatu sport } \\
\text { hitam dan peci hitam. } \\
\text { Gerakan Tubuh } \\
\text { Menggunakan gerakan }\end{array}$ \\
\hline
\end{tabular}




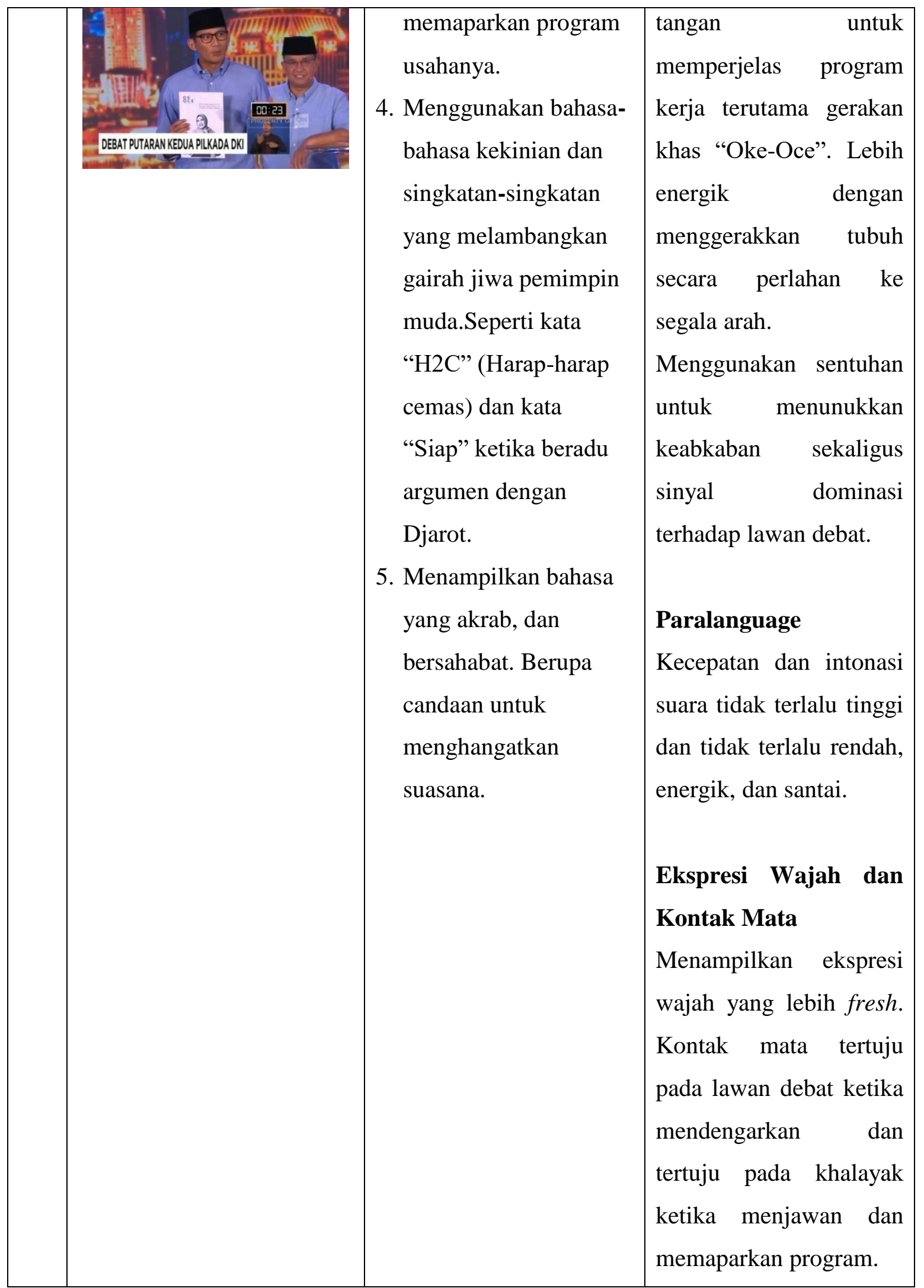




\section{Analisis Konotatif Isu Politik Pasangan Calon}

1. Ahok-Djarot mengusung Visi Jakarta Modern. Sedangkan Anies-Sandi mengusung Visi Jakarta Maju. Singkat kata "modern vs. maju”.

2. Ahok-Djarot lebih menekankan pada peran sentral pemerintah dalam membangun infrastruktur di wilayah DKI Jakarta. Sementara Anies-Sandi lebih menekankan pada peran pemerintah sebagai pemimpin masyarakat sehingga seluruh masukan anggota masyarakat harus dilibatkan dalam pembangunan infrastruktur di wilayah DKI Jakarta.

3. Ahok-Djarot lebih banyak memaparkan program kerja yang telah dikerjakan dan masih dikembangkan ke depannya. Sementara AniesSandi, memaparkan program kerja yang relatif baru bagi pembangunan Jakarta namun tetap menegaskan adanya kesinambungan dengan program kerja Gubernur-gubernur sebelumnya.

4. Ahok-Djarot diuntungkan dalam pemaparan program kerja dikarenakan telah mengerjakan sebahagian program tersebut selama menjabat sehingga mampu menyerang program Anies-Sandi yang dicap masih sebatas janji. Di sisi lain, Anies-Sandi diuntungkan karena mampu mengkritik program Ahok-Djarot yang belum terealisasi dan tidak pro rakyat kecil melalui pertanyaan-pertanyaan seputar pulau reklamasi dan penggusuran.

5. Program Ahok-Djarot lebih bersifat top-down dimana pemerintah melalui pertimbangan pakar dan perwakilan masyarakat merumuskan program kemudian meminta masyarakat untuk berperan aktif dalam eksekusinya. Sementara program Anies-Sandi lebih bersifat bottom-up, dimana pemerintah melibatkan masyarakat luas sejak awal perumusan program hingga eksekusinya. Contohnya pada kebijakan penyediaan perumahan rakyat. Ahok-Djarot memilih membangun sendiri rumah susun dan meminta warga yang direlokasi untuk pindah ke rumah susun yang disediakan tanpa harus membayar sewa meski tetap dikenakan biaya perawatan. Keunggulan model ini adalah masyarakat tak perlu lagi khawatir rumahnya ditarik perbankan karena tak mampu membayar 
hipotek sebab aset rusun merupakan aset pemerintah yang dihibahkan kepada masyarakat. Sementara Anies-Sandi lebih terpikir untuk memberi keluasan kepada masyarakat untuk memilih jenis rumah yang ingin ditinggali, apakah rumah susun ataukah rumah tapak. Pemerintah tidak lagi membangun rumah, namun sebatas memberikan keringanan hipotek dengan harga terjangkau dan tanpa uang muka.

\section{Analisis Konotatif Citra Kandidat:}

1. Ahok-Djarot mencitrakan diri sebagai pemimpin yang tegas dan lugas dalam mengeksekusi kebijakan-kebijakan pemerintah. Sedangkan AniesSandi mencitrakan diri sebagai pemimpin yang dekat dan mengayomi masyarakat dalam melaksanakan kebijakan-kebijakan yang berpihak pada rakyat.

2. Ahok-Djarot cenderung menggunakan kalimat "Kami sudah membangun ini atau kami sudah melakukan ini" untuk memberi kesan kepada pemilih bahwa mereka telah merealisasikan program kerja secara nyata dan bukan masih sebatas janji seperti pihak lawannya.

3. Anies-Sandi mencitrakan diri sebagai pemimpin yang pro rakyat dengan menolak reklamasi dan relokasi melalui penggusuran. Hal ini sekaligus menjadi argumen untuk menyerang kebijakan dan program kerja lawannya.

4. Ahok berapi-api namun tetap berusaha santun. Djarot santun namun agak kaku. Anies cakap dalam beretorika namun terkadang memakai bahasa ilmiah dan analogi yang sulit dipahami. Sandi energik namun kadang menunjukkan sikap bercanda terhadap lawannya.

\section{Positioning Politik Kandidat Melalui Pesan Verbal dan Nonverbal}

\section{Basuki Tchahaya Purnama (Ahok)}

Ahok adalah kandidat petahana Pilakada Jakarta 2017.Jauh hari sebelum tahapan kampanye namanya sudah banyak menjadi pembicaraan di berbagai 
media.Posisi petahana menjadikan Ahok sebagai simpul dinamika komunikasi politik di Pilkada Jakarta.Mulai dari isu-isu kepemerintahan, hukum, politik, hingga SARA melingkupi. Berbagai isu inilah yang juga turut melatari komunikasi politik yang ditunjukkan ahok dalam debat Pilkada putaran kedua.

\section{Tanda Verbal}

Di masyarakat politik Indonesia Ahok sering distigmatisasi sebagai politisi atau Gubernur yang memiliki gaya komunikasi yang khas. Diantara banyak penilaian yang muncul, tidak sedikit yang mengangap bahwa gaya berbicara Ahok itu karakternya "keras" bahkan "kasar". Persepi "keras dan kasar" merupakan contoh konotasi negatif dari pesan-pesan verbal dan non-verbal yang dikomukasikan Ahok.

Peneliti menemukan beberapa pesan verbal Ahok dalam debat Pilkada Jakarta yang mendukung stigma kasar tersebut. Menurut Tarigan, kata-kata kasar adalah kata-kata yang terdengar kasar dan mendapat nilai rasa kasar. Kata ini diangap kurang sopan jika disampaikan kepada orang yang disegani.Salah satu indikasi utama kata-kata kasar adalah digunakan oleh penutur yang sedang marah dan dalam kondisi emosi yang tinggi. ${ }^{5}$

Salah satu contoh perkataan kasar Ahok adalah ungkapan Ahok kepada“jangan membohongi..."Anies.Kalimat ini cukup menarik perhatian karena menjadi kalimat pembuka tanggapan dengan sedikit penekanan nada (paralangue).Menurut hemat peneliti,makna dari kata "bohong"sebenarnya bisa dikodekan dengan pilihan kata yang lebih santun, contohnya "berkata tidak benar", "keterangan yang keliru".Dalam ilmu retorika, komunikator harus mampu menarik simpati khalayak dengan mengelola kesan positif dari dirinya (pathos).Alih-alih menjadi komunikator yang hebat, Ahok justru menonjolkan kelemahannya dalam berorasi.

Pada konteks yang lain, kata "jangan membohongi" juga memiliki keterkaitan dengan memori kolektif masyarakat Jakarta. Frase “jangan

\footnotetext{
${ }^{5}$ Hendry Guntur Tarigan, Pengajaran Semantic, (Bandung:Angkasa, 2009).
} 
membohongi" berpotensi me-recall ingatan khalayak terkait klausa populer “jangan mau dibohongi pakai Al-Quran” yang memicu konflik sosial dan psikologis masyarakat.Menggiring ingatan khalayak pada kasus penistaan agama yang sedang berperkara di pengadilan bukanlah langkah retorik yang tepat bagi posisi Ahok sebagai “pihak penista".Analisis konotatif ini menguatkan positioning bahwa Ahok bukanlah orator yang baik.

Meski demikian bukan berarti Ahok tidak memiliki kelebihan.Konotasi positif ditandai dengan penjelasan Ahok sebagai kandidat petahana yang telah banyak melaksanakan program pembangunan.Penekanan bukti kinerja adalah senjata pamungkas bagi setiap kandidat petahana.

Hal ini senada dengan hasil pengamatan Prof. Hafied Cangara mengatakan Bahwa "Ahok bisa berbicara banyak tengtang pembangunan karena dia sudah pengalaman menjadi pemimpin daerah". 6

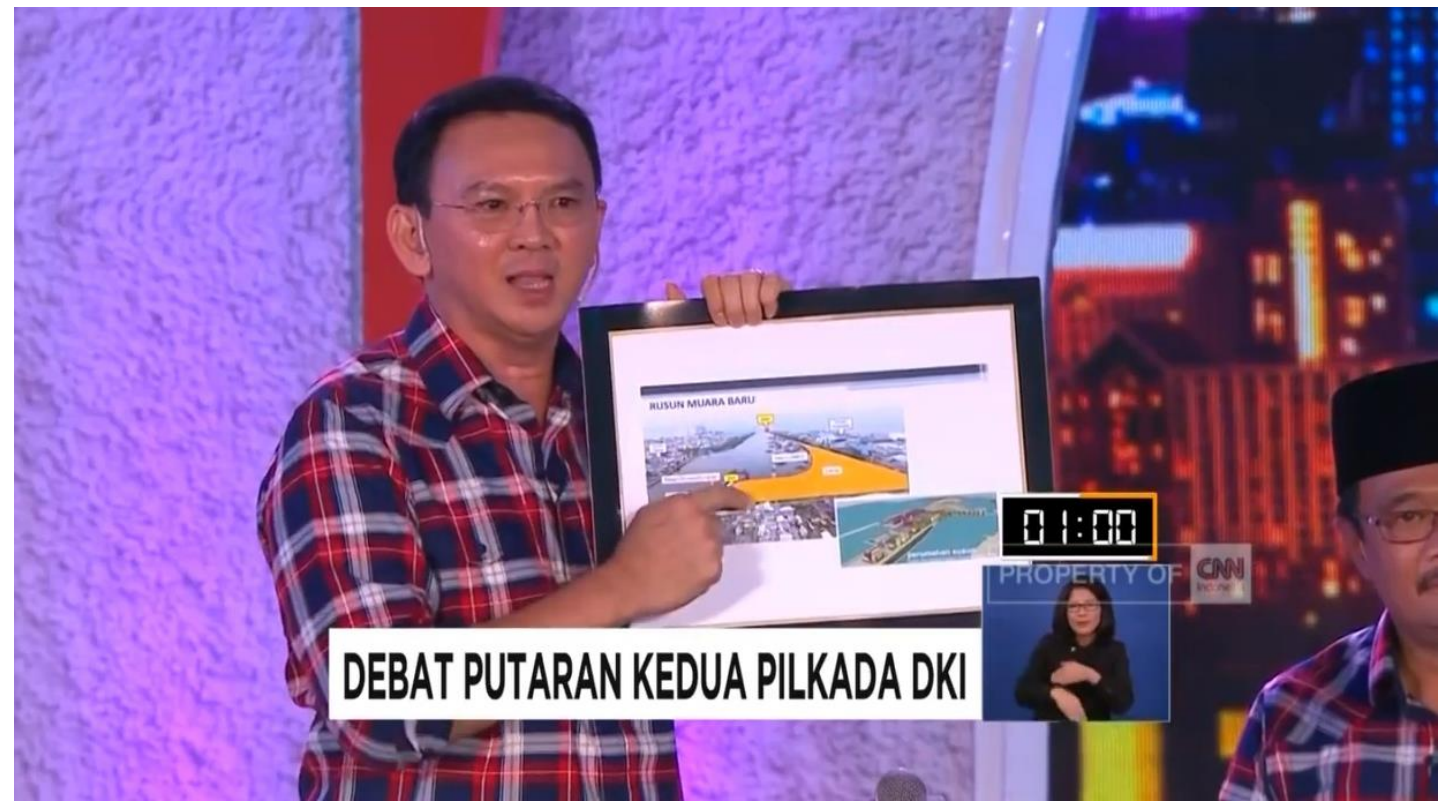

Gambar 1: Ahok saat menjelaskan program Muara Angke (Durasi 01.06.56)

Ahmad Sabir, selaku informan ke-2 yang juga direktur komunikasi konsultan politik Lensa Demokrasi menilai Ahok berhasil membangun argumentasi logis tengtang kinerjanya sebagai Gubernur Jakarta.

${ }^{6}$ Hafied Cangara. Op.cit 
"Dengan gaya khasnya ia berhasil merasionalisasikan kebijakan-kebijakan non populer yang diambil seraya membeberkan bukti-bukti keberhasilan kinerjanya.Pemilihan kata yang digunakan lebih pada upaya meyakinkan rasio publik dengan logika-logika sederhana".

Selain itu, Ahok cukup cermat dalam menanggapi isu SARA yang dialamatkan kepadanya, berikut pernyataan Ahmad Sabir terkait tanggapan verbal Ahok:

"Menjawab sentimen SARA, argumen yang diutarakan Ahok juga kuat. Tentang bagaimana ia pernah sebagai representasi minoritas berhasil menjadi bupati bagi komunitas yang mayoritas. Bagaimana ancaman tidak disholatkan bagi jenasah pendukungnya juga pernah terjadi di kampungnya, Bangka Belitung. Toh rupanya ia masih terus dipercaya masyarakat Bangka Belitung hingga ke kursi DPR RI berkat gaya kepemimpinannya yang tidak membeda-bedakan".

\section{Tanda Nonverbal}

Selain pesan verbal, Ahok juga menunjukkan beberapa pesan non-verbal mulai dari penampilan, gerak tubuh, paralangue, dan ekspresi wajah dan kontak mata.Dari segi penampilan, Ahok mengenakan pakaian yang sudah menjadi seragam kampanye sejak berpasangan dengan Jokowi pada Pilgub 2012.Seragam kampanye kotak-kotak menurut Nevi Ervina, juru bicara tim pemenangan AhokDjarot, menjelaskan ide baju kampanye kotak-kotak itu berasal dari Ahok sendiri

"Idenya dari Pak Ahok sendiri karena Beliau ingin menyampaikan bahwa baju kotak-kotak itu identik dengan para pekerja. Jadi jika bekerja bersamasama, apa pun yang kita lakukan bisa kita raih," kata Nevi Ervina melalui sambungan telepon"7

Dari sini terlihat konsistensi positioning politik Ahok baik secara verbal maupun penampilan visual dirinya sebagai pekerja yang ulet.

Aspek nonverbal berikutnya adalah gerakan tubuh.Konotasi "pekerja" pada pesan verbal Ahok berkesuasian dengan bahasa tubuh Ahok yang ditunjukkan dengan keaktifannya menggerakkan tangan.Namun demikian, Ahok masih sangat membatasi ruang geraknya dengan cenderung berdiam di tempat saat berbicara.Perpaduan gerakan tubuh seperti ini dapat bermakna bahwa Ahok bukanlah tipikal yang suka mengekporasi lebih jauh sesuatu. Dia cukup puas

\footnotetext{
${ }^{7}$ http://www.antaranews.com/berita/595154/makna-seragam-kampanye-kotak-kotak-ahok-djarot
} 
dengan berdiam d tempat tanpa berusa menjejaki hal-hal lain. Jika dihubungkan dengan pendekatan kebijakan, hal ini menandakan sikap pemimpin yang tidak mengutamakan aspirasi dari lingkungannya. Kebenaran kebijkan ditentukan dari "titik" dimana dia berdiri dan bukan dari sumber-sumber yang lain.

Berikutnya adalah aspek paralangue atau parabahasa.Dari sisi tanda denotasi Ahok berbicara dengan nada suara tidak terlalu konsisten.Kadang keras kadang lembut.Begitupun dengan kecepatan berbicara.Kontrol terhadap nada bicara sangat penting dalam komunikasi.Ketidakteraturan ini pada pemaknaan tingkat berikutnya dapat berkonotasi keidakmampuan Ahok untuk mengendalikan diri, tidak tenang dan menguasai dirinya sendiri.Kesan konotatif terebut tentu tidak membuat Ahok menjadi orator yang baik di mata khalayak.

Terakhir adalah ekpresi wajah dan kontak mata.Yang mencolok dari aspek ini adalah perilaku Ahok yang cenderung menghindari kontak mata pada lawan debat baik ketika mendengarkan maupun ketika memaparkan.Padahal pada sesi akhir Ahok dan Anis saling lempar pempar pertanyaan dan tanggakapan.Kontak mata bisa menjadi indikator perhatian sesorang terhadap lawan bicaranya.Kontak mata juga menjadi tanda penghargaan kita pada lawan bicara sebagai bentuk kesadaran sesorang terhadap keberaadaan lawan bicaranya. Kontak mata pula dapat menjadi indikasi rasa takut atau "inferior" sesorang dihadapan orang lain, atau menjadi tanda kurangnya kepercayaan diri sesorang. Hal ini sangat menurungkan kualitas komunikasi Ahok pada sesi debatnya dengan Anis.

\section{Djarot Saifullah Hidayat}

\section{Tanda Verbal}

Tidak jauh beda dengan materi debat pasanganya, Djarot lebih banyak focus pada pemaparan program kerja yang telah dilaksanakan. Informan Ahmad sabir mengatakan."Djarot lebih diarahkan menyentuh akal penonton ketimbang berupaya membangkitkan empati public".Pasangan petahana ini banyak dikritik dari aspek kebijakannya yang dinilai kurang memihak terhadap rakyat kecil reklamasi,sumber waras, dan penggusuran- sehingga penting bagi Ahok dan Djarot melakukan couter attack dengan penjelasan program. 
Djarot menggunakan kata-kata yang bersifat halus seperti "melayani dengan hati” kata-kata yang sopan, santun, bertata karma yang khas birokrat.Dengan begitu, djarot pun tampil sebagai sosok santun yang mampu "mengimbangi" karakter Ahok.Tentu latar budaya tutur orang jawa cukup mempengaruhi perilaku komunikasi Djarot.Stereotip orang jawa dalam berbicara adalah lembut dan santun, menghindari kata-kata kasar meski dalam kondisi "marah".Secara politis, kesan ini menjadi strategis untuk meyakinkan pemilih yang konser denga perilaku komunikasi calon Gubernurnya.

\section{Tanda Nonverbal}

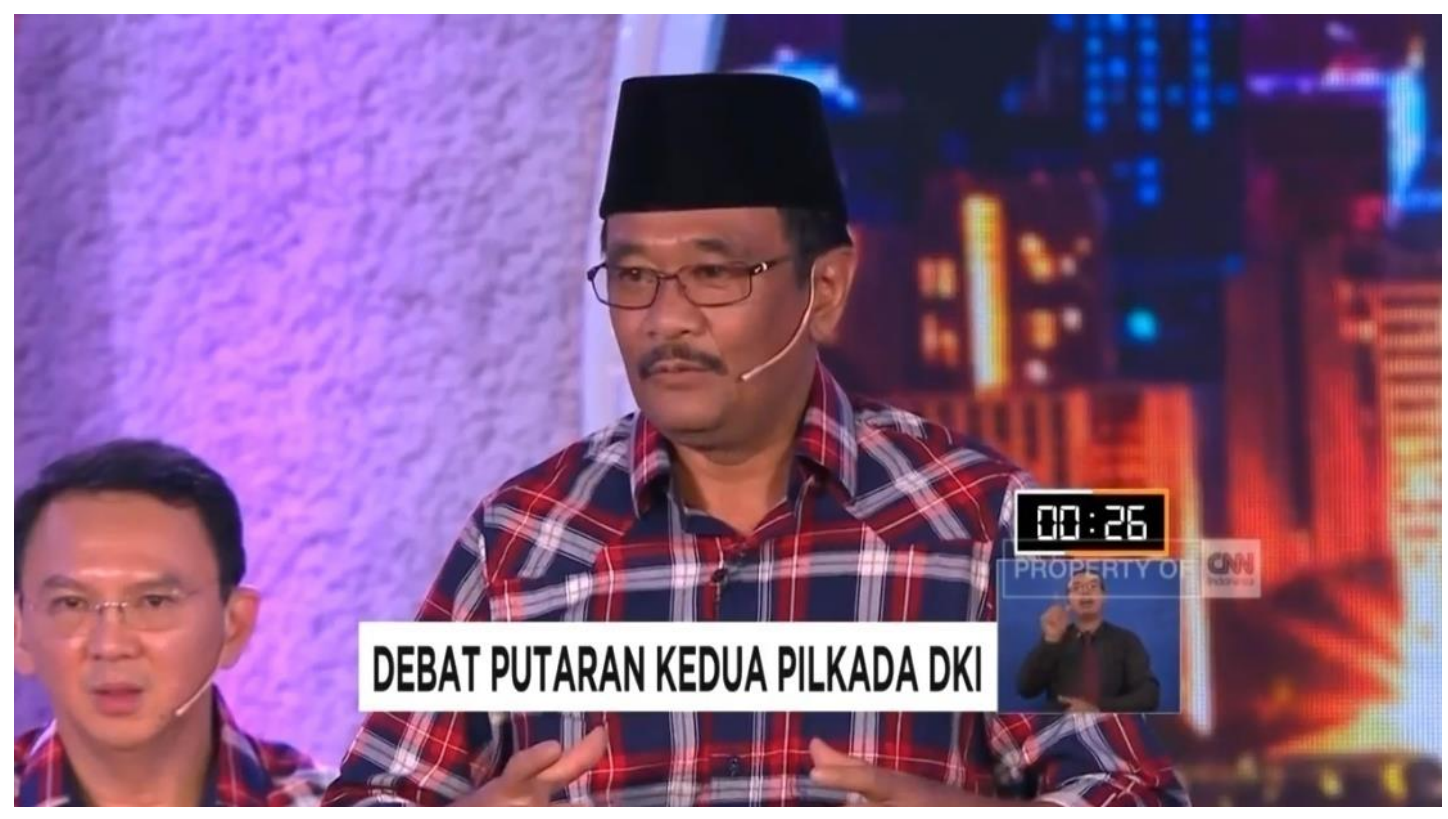

Gambar 2 : Djarot saat menanggapi program OK-OCE Anis-Sandi

\section{(Durasi 00.40.01)}

Tanda nonverbal pertama adalah terkait penampilan visual Djarot.Jika dibandikkan dengan Ahok, pembeda utama adalah peci hitam yang dikenakan Djarot. Makna umu peci hitam adalah simbol Nasionalisme bagi pemakainya. Tapi saat dikontekskan dengan isu SARA, simbol peci juga berkonotasi sebagai pemimpin yang relijius.Hal ini menjadi relevan untuk menjelaskan pertanyaan khalayak tentang orientasi keagamaan pasanagn Ahok-Djarot.Di tengah sentimen masyarakat Jakarta tentang isu keaagamaan, Djarot tampil dengan peci untuk merekonstruksi tudingn "sekuler" terhadap citra pasangannya.Adapun penampilan 
lainnya seperti baju memiliki konotasi yang serupa dengan pesan visual yang diatribsi oleh Ahok.

Berikutnya adalah gerakan tubuh Djarot.Tidak sulit untuk menilai Djarot sebagai komunikator yang kurang aktif diatas panggung.Di banyak kesempatannya berbicara, Djarot hanya mengandalkan sedikit gerakan tangan saat mengiriki pesan verbal yang dia samapaikan.Lagi-lagi perilaku kaku di tempat ini memiliki konotasi khusus jika dihubungkan dengan kesan tipe kepemimpinan kandidat, bahwa Djarot bukanlah tipe pemimpin eksporatif terhadap kondisi seosial disekitarnya. Pada titik level tertentu pesan nonverbal ini dapat dimaknai sebagai pribadi pemimpin dengan tipe kepemimpinan yang Top-Down. Djarot seolah mengisolasi zona mapannnya dalam hal kebijakan seoal segala sesuatu telah terkonsepkan dengan baik dan tidak perlu aktif mengecek kenyataan disekelilingnya.

Selanjutnya pesan nonverbal parabahasa Djarot.Dibanding denggan Ahok, Djarot jauh lebih tenang dengan intonasi suara yang datar dan pelan.Hal ini seidaknya memiliki dua konotasi.Pertama, Djarot adalah tipe pemimpin yang dewasa dalam menyikapi perbedaan politik dengan lawannya.Dalam situasi pertarungan politik yang memuncak dengan kompleksitas konfil sosial yang menyertainya, Djarot masih bisa mengendalikan diri dan tetap mengedepankan penyelesaiain secara objektif yakni dengan adu argumentasi. Hal ini tidaklah mengherankan jika melihat latar belakang Djarot yang tidak saja seorang politisi melainkan juga seorang akademisi (baca: profile Djarot Saifullah Hidayat). Pengalamannya dalam wacana keimulan sebagai dosen turut mempengaruhi gaya komunikasinya di atas panggung politik. Pandangan ini sejalan dengan pengamatan informan Ahmad Sabir sebagai berikut:

"Djarot terlihat lebih santai dan percaya diri ketimbang pasangan mereka masing-masing.Tak tampak adanya indikasi rasa gugup baik dari Djarot maupun Sandi sepanjang debat berlangsung. Djarot terlihat begitu tenang menjelaskan program-program di masa pemerintahannya dan bukti-bukti keberhasilan kinerja. Dengan intonasi suara yang datar dan pelan, Djarot mengkritik rival-rivalnya secara santun serta mengcounter kritik yang dilayangkan rival dengan tenang pula." 
Kedua, gaya vocal Djarot yang datar dan pelan juga memiliki konotasi politik bahwa dirinya tidaklah memiliki ambisi kekuasaan. Dia tidak terlalu gelisah dengan kemungkinan kekalahannya dalam pemilihan Gubernur nanti.Berbeda dengan Ahok, yang sulit menutupi kegugupannya yang sarat dengan beban psikologis.Boleh jadi pertarungan ini memang lebih banyak menguras energi dan sumber daya calon Gubenur dianding wakilnya. Adapun aspek nonverbal terakhir dari Djarot terkait ekspresi dan kontak mata.

\section{Anis Rasyid Baswedan}

\section{Tanda Verbal}

Setiap kandiat sudah memilki citra awal (predisposition) dimata masyarakat sebelum pelaksanaa debat. Demikian juga Anis Basedan yang sudah banyak tercitrakan di media sebagai sosok yang intelek. Selain karena gaya retorika verbalnya yang baik, Anis juga sangat dekat dengan dunia penndidikan, bahkan telah menduduki jabatan seperti rektor Universitas Paramadina dan juga Menteri Pendidikan dan Kebudayaan RI.

Citra intelek tersebut di atas kembali dikuatkan melalui pesan verbal Anis dalam debat final Pilkada Jakarta. Kepiawan anis dalam memilih kata-kata kembali ditunjukkan dalam debat. Namun jika diamati secara semiotis aspek retorika dari pesan verbal anis lebih banyak ditujukan untuk menggugah perasaan simpati public dibanding rasionalisasi program sebagaimana yang dilakukan lawan debatnya.Berikut adalah uraian informan konsultan politik Ahmad Sabir terkait pesan verbal Anis:

"Anies lebih banyak mengeksplor sisi kemanusian yang sepatutnya dipertimbangkan dalam kebijakan pemerintah.Dengan rasionalitas sederhana dan mudah dicerna, Anies memilih kata-kata yang dianggap lebih menyentuh emosi penonton.Bahasa verbal yang digunakan Anies lebih ditujukan untuk membangkitkan empati publik atas penderitaan wong cilik ketimbang fokus merasionalisasikan program-programnya. Seperti saat ia menyebut bahwa warga bukit duri tahu persis arti kebohongan dalam kampanye, reklamasi yang hanya akan jadi pemukiman mewah dan bukan ditujukan untuk menjadi milik nelayan, hingga pada ketidakadilan yang dialami masyarakat pinggir kali di Kampung Gugut yang hanya berjarak 4 km dari balai kota." 
Anis mempertegas posisinya sebagai opisisi dan penantang petahana dengan banyak mengesploitasi kelemahan Ahok baik dari sisi kepribadiaan maupun dari sisi kebijakannya sebagai gubernur.Serangan Anis terhadap pribadi Ahok juga berkonotasi bahwa Anis adalah antitesa dari Ahok, Anis adalah yang "bukan kelemahan" Ahok. Konstruksi ini menjadi strategis ditengah opini publik terhadap Ahok yang sudah banyak negatif semenjak bergulirnya kasus hokum penista Agama di media mainstream. Dari aspek kebijakan Anis lebih meyakinkan khalayak bahwa dia akan lebih banyak melibatkan masyarakat dalam mengambil kebijakan. Dengan kata lain Anis mengkonstruksi tipe kepemimpinannya yang bottom-up.

\section{Tanda Nonverbal}

Sebagai pernyataan pembuka untuk kesan non verbal Anispeneliti kutip dari informan Prof. Hafied Cangara melalui deskripsi singkatnya yang mengatakan “Anis itu sopan, intelek, sabar,... mewarisi budaya Sunda Jawa”.

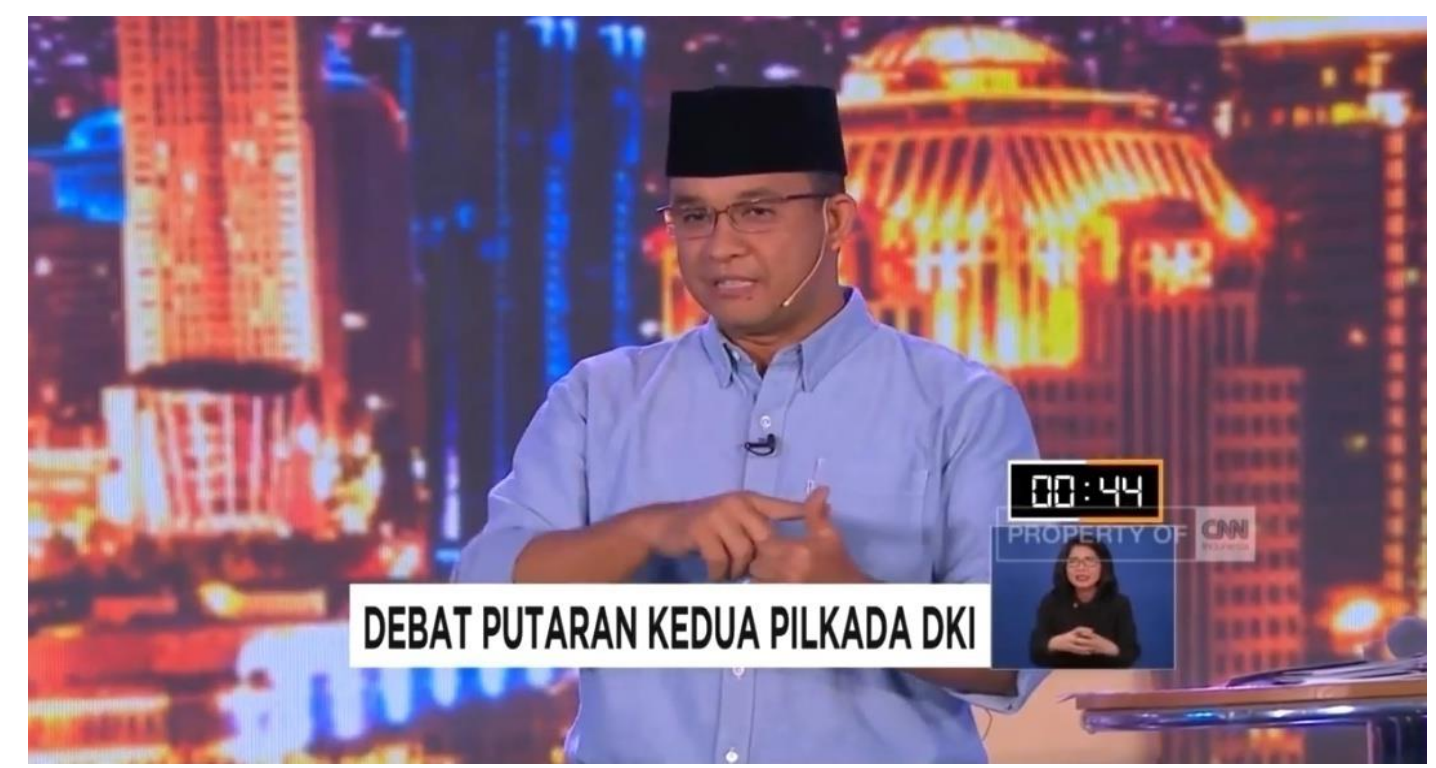

Gambar 3. : Anis saat menjelaskan program OK-OTRIP (Durasi 50.04)

Dari segi penampilan Anis tampil rapi dengan Kemeja berwarna biru muda dengan lengan baju tergulung dan celana panjang berwarna coklat muda. Rim dengan setelan rapi kemeja masuk ke dalam celana. Memakai kacamata, sepatu hitam dan peci hitam.Anis adalah toko pendidikan, dan citra ini ditunjukkan 
melalui penanda-penanda visual yang dikenakannya.Selain jinis kain dan warna, gaya berpakaian Anis sebenarnya tidak jauh beda dengan kerapian lawannya. Hanya saja ada yang berbeda dari pemilihan warna baju yang dikenakan jika melijat kebiasaannya selama ini dalam masa kampanye.Anis-Sandi dikenal selalu berpakaian kemeja putih dalam berkampanye seperti yang biasa dikenakan pasangan Prabowo-Hatta dalam pemilihan presiden 2014. Hal ini tidaklah begitu mengherankan mengingat Partai Gerindra pimpinan Prabowo adalah partai pengusung Anis-Sandi dalam Pilgub Jakarta 2017 bersam dengan PKS.Kembali pada baju biru muda, warna biru muda jika dikembalikan dengan eksistensi naturalnya selalu diasosiasikan dengan warna langit.Dan sifat langit itu adalah melingkupi bumi dengan segala isinya.Filosofi ini memiliki kesesuain konotatis dengan seruan-seruan verbal Anis yang sering menekankan pentingnya pemimpin yang bisa merangkul dan mengayomi seluruh rakyatnya. Dengan kata lain, pasangan Anis-Sandi membangun mitos heroik "langit dan bumi" pada malam debat final pilkada Jakarta. Anis-Sandi adalah pemimpin yang siap merangkul semua kalangan masyarakat termasuk "etnis minoritas dan keturunang asing" yang ada di Jakarta.

Adapun kacamata adalah symbol kedewasaan sekaligus symbol intektualitas Anis dihadapan khalayak. Sama dengan wakilnya Sandi, atribut visual ini bermakna kekompakan karakter antara keduanya. Bahwa mereka hadir sebagai calon pemimpin Jakarta yang sudah selesai dengan penyesuaain karakter dan siap bekerja untuk rakyat.Dan terakhir peci yang juga menjadi tanda nasionalisme keduanya.

Tanda verbal berikutnya adalah gerakan tubuh.Pada setiap kesempatannya berbicaran, Anis selalu mengefektifkan gerakan tubuh dalam menjelaskan program kerja. Seperti menjelaskan poin-poin program menggunakan gerakan tangan dan jari. Diapun sesekali beranjak dari titik berdiirnya saat awal memuli berbicara. Keaktifannya di atas panggung kembali mendukung konotasi tipe kepemimpinannya yang bottom-up sekaligus mempertegas pribadinya sebagai pemimpin yang memilki kemampuan komuniaksi yang baik. 
Selanjutnya olah vocal Anis yang memiliki intonasi suara yang tenang dan tidak terlalu cepat, dan artikulasi jelas dengan ritme terjaga. Nada suara yang terkendali dapat adalah penanda dari karakter pemicara yang bisa mengontrol diri.Menjaga etika dan perilaku komunikasi adalah bagian dari positioning dari Anis sebagai antitesa dari kepribadian Ahok.Khalayak menjadi mudah membedakaan karakter pribadi keduanya dari segi vocal berbicara.Selain itu, ritme nada suara Anis yang terpola dan bertingkat juga merupakan strategi retotik untuk mengugah emmosi khalayak (pathos).Sudah dijelaskan sebelumnya bahwa anis secara verbal lebih menyasar persaaan khalayak dibading rasionalisasi program, dan pesan ini dilengkapi dengan pesan nooverbal paralanguage-nya.

Terakhir adalah ekpresi wajah dan kontak mata.Anis terkadang memperlihatkan ekpresi cempberut dan menunduik saat mendengarkan lawan debatnya berbicara. Hal ini mengindikasikan respon negatif terhadap apa yang didengarkan Anis. Ada dua kemungkinan, pertama, Anis merasa terintimidasi dengan banykanya pemaparan program yang telah dilakukan lawannya (kampanye khas petahana).Kedua, Anis secara kognetif tidak sepakat dengan logika program lawannya, misalnya kebijakan reklamasi dan penggusuran yang bagu Anis tidak memperdulikan nasib rakyat kecil.Ambiguitas konotasi ini menjadi sulit untuk digeneralisasi dalam perpspektif khalayak umum. Namun tentu positif negatif dari pesan visual ini akan berkesesuaian dengan predisposisi khalayak. Artinya, bagi khalaya pendukung Anis makan akan dikon versi ke hal yang positif dan sebalinya bagi khalayak pendukung Ahok-Djarot.

Terlepas dari interpretasi ganda di atas, Anis terlihat mampu memaksimalkan kontak mata terhadap khalayk. Anis mempraktekkan konsep kontak mataMark Knap yang mana pembicara yang baik akan mengarahkan kontak mata kepada seluruh sisi khalayak dan tidak berdiam lebih dari sepuluh detik pada satu titik pandang saja.Strategi ini mampu mengisolasi perhatatian khalayak pada komunikator.

Meski demikian, Anis tidak begitu menjaga kontak mata terhadap lawannya Ahok dalam sesi Tanya jawab.Secara normal Anis adalah tipe komunikator yang concern dengan kontak mata pada khalayak tapi tidak pada Ahok.Namun 
kebiasaan ini menjadi berbeda data berhadapan Ahok.Adegan ini semakin mempertegas sempitnya "ruang kompromi" antara keduanya sekaligus tanda luasnya "jurang konflik".

\section{Sandiaga Salahudin Uno}

\section{Tanda Verbal}

Secara verbal Sandi meyakinkan khalayak bahwa dirinya telah berpengalaman dalam mengelola keuangan melalui penjelasannya dalam debat tengtang prestasi yang dia peroleh saat masih menjadi pengusaha. Seperti diketahui bahwa sosok Sandi sangat lekat dengan image usahawan muda yang sukses. Profil pribadi inilah yang sering Sandi sebutkan untuk menguatkan keyakinan masyarakat Jakarta atas kemampuannya memajukan Jakarta sebagaimana dia telah memajukan sejumlah perusahaan yang pernah dia pimpin.

\section{Kutipan Sandi tentang Bisnisnya}

OCE-OKE, konsistensi Sandi dalam debat politiknya juga ditunjukkan melalui penjelasan verbal program OCE-OKE yang diusungnya. Program ini diklaim sebagai terobosan dalam mengatasi masalah ekonomi dan kesejateraan masyarakat Jakarta khususnya dalam menggenjot lahirnya wirausahawan baru.Dengan program ini pula Sandi meyakinkan masyarakat Jakarta untuk memgurangi angka penganguran.

Selain uraian program, Sandi juga lihai menyisipkan sanjungan kepada lawan debatnya.Bahkan dia tidak segan-segan menginterupsi dan bertanya langsung kepada Djarot terkait istilah yang kurang jelas.“KUA itu apa ya pak,... supaya pemirsa di rumah juga tau" Dengan pandainnya, Sandi menambahkan bahwa dia bertanya agar khalayak di rumah juga tau.Sikap perhatian ini berhasilditunjukkan dengan sangat halus (subtle) dan estetik.Memecah kekakuan dengan sisipan perhatian.

Pendekatan emosional (pathos) dan rasional (logos) yang dipraktekkan Sandi cukup menggugah emosi khalayak yang ditandai dengan riakan dan tepuk tangan yang meriah. 
Analisis di atas senada dengan pengamatan konsultan politik, Ahmad Sabir, berikut keterangannya:

"Tak jauh berbeda dengan Anies, bahasa verbal yang digunakan Sandi juga lebih mengarah untuk menggugah empati publik atas penderitaan yang dialami masyarakat kecil akibat kebijakan non-populer petahana.Dibarengi argumen-argumen rasional dan pilot project program yang berhasil dilaksanakan, Sandi setidaknya berhasil menunjukkan bahwa gagasangagasan mereka bukanlah omong kosong. Pujian yang diberikan Sandi kepada Djarot sebagai mantan walikota yang perlu dimintai nasihat dipertengahan debat juga merupakan pedang bermata dua. Sebab tak hanya memuji wisdom Djarot, Sandi juga memuji kebesaran hati Djarot menerima jabatan wakil gubernur sementara kans Djarot sesungguhnya lebih pantas jadi gubernur ketimbang Ahok."

\section{Tanda Non-Verbal}

Dariaspek penampilan, Sandi menunjukkan penampilan yang sedikit berbeda dengan tiga kandidat lainnya.Mulai dari jam tangan yang dikenakan, sepatu, hinga baju yang tidak dirapikan masuk ke dalam celana.

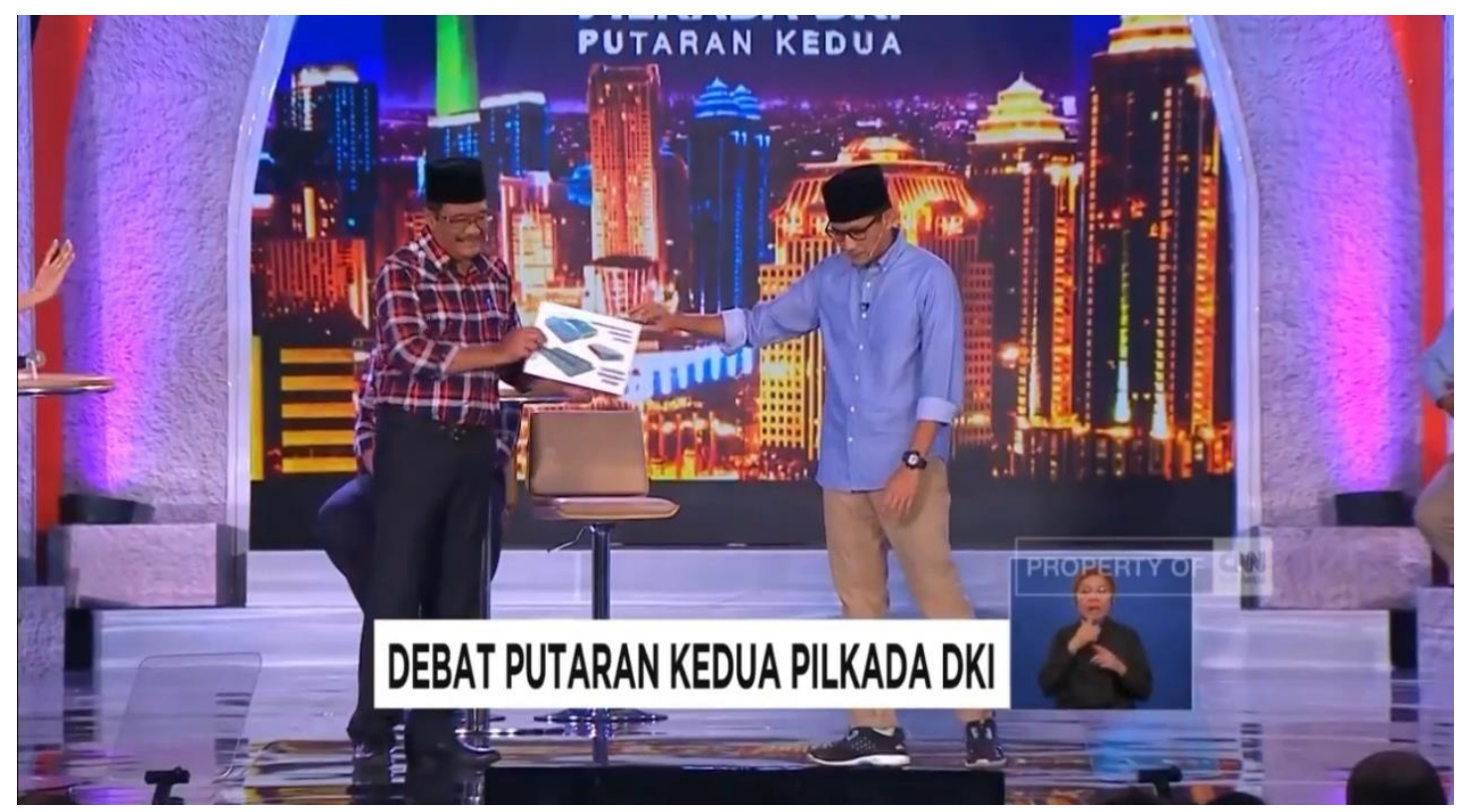

Gambar 4: Adegan Sandi mengembalikan alat peraga yang dia minta dari Djarot

(Durasi 01.22.27)

a. Jam tangan sport. Kesan beda ini ditunjukaan melaui sepatu dan jam tangan yang dikenakan oleh sandi. Jam tangan sportyang melingkar di 
pergelangantangan Sandi bermakna konotasi bahwa dia adalah pribadi yang tidak formalistik tapi dia adalah sosok yang fungsional dan efektif yang mana dalam terjemahan awamnya sepadan dengan kesan "gaul" atau "easy going". Melalui simbol jam tangan ini Sandi membangun mitos bahwa dia adalah pemimpin yang siap bekerja dilapangan, siap bekerjasama dengan siapa saja dan dimana saja tanpa ada batas-batas "protokoler" dengan segala drama formalistiknya yang membatasi.

b. Sepatu sneaker.Demikian juga dengan jenis sepatu yang Sandi kenakan. Di saat kandidat lain masih setia dengan sepatu formal hitam berbahan kulit, sandi memilih untuk mengenakan sepatu sneaker. Dalam dunia fashion jenis sepatu sneaker adalah trend bagi konsumen muda.Sneaker adalah identitas sense of fashion kalangan remaja dan pemuda. Sneaker adalah sebuah pesan konotatif bahwa pemakainya adalah orang yang secara kognisi up to date, secara emosional memiliki kepekaan estetis, dan sekaligus secara sosial menegaskan image "muda".Tentu makna konotasi yang demikian sangat penting bagi komunikator politik seperti Sandiaga Uno. Dia ingin mengkonstruksi mitos bahwa dirinya adalah pilihan pemimpim masa depan yang bisa mewakili jiwa (frame of reference)remaja dan pemuda. Mitos ini secara electoral politik memiliki efek signifikan mengingat remaja dan pemuda sebagai pemilih pemula cenderung untuk menentukan pilihan berdasarkan alasan-alasan emosional-psikologis.

c. Kacamata minus.Kesan muda, inovatif, dan sukses belum cukup untuk mengungulkan pribadi Sandi sebagai calon pemimpin yang cerdas. Dalam debat pilkada Jakara Sandi mengenakan kecamata minus yang mana secara konotatif identik dengan orang cerdas dan berpengetahuan luas. Budaya pertandaan masyarakat di Indonesia sejak lama menghubbungka kacamata dengan kecerdasan otak seseorang. Orang dengan kacamata

d. Peci hitam.Seperti duakandidat lainnya, memakai peci hitam merupakan identitas bagi kaum pria bangsa Indonesia. Latar historis dari peci hitam seperti yang telah dijelaskan pada pembahasan kandidat sebelumnya memiliki efek mitos yang sama pada Sandiaga Uno. Dalam perspektif komunikasi 
politik atau lebih spesifik dalam konteks kampanye, Sandi mencitrakan dirinya tidak saja sebagai usahawan berprestasi tapi juga mitos seorang negarawan yang pemberani.

Berikutnya, gerakan tubuh (body language) Sandiaga Uno.Hal yang paling menonjol dari Sandi dibanding kandidat lainya adalah keaktifannya bergerak diatas panggung.Perilaku Sandi tersebut tak luput dari amatan Ahmad Sabir:

"Penampilan yang tanpa beban tampak saat Sandi mengajak Djarot untuk salam pipi pada sesi debat interaktif. Perilaku ini menonjolkan sikap ramah Sandi ke publik. Disisi lain Sandi juga tak lupa menonjolkan dominasinya atas Djarot saat ia mengambil slide dari tangan Djarot untuk ditunjukkan ke publik"

Dibalik kelincahan Sandi dalam menguasai panggung terdapat pemaknaan kuat. Pertunjukan meta komunikasi di atas dilakukan secara sengaja untuk mengkonstruksi mitos politik Sandi. Gerak mendekat ke lawan debat dan mengambil sesuatu darinya adalah ilustrasi epic yang ditunjukkan Sandi sebagai pemimpin yang siap menghadapai persoalan di hadapannya. Tidak berhenti sampai disitu, Sandi sekaligus mengesankan bahwa dia bukanlah tipikal yang duduk diam menunggu solusi datang melainkan aktif menyelami masalah dan mencari solusi bersama. Body movement tersebut sekaligus mencitrakan pendekatan kebijakan Sandi dalam pemerintahan, ia aktif menyerap aspirasi dari bawah "buttom-up".Ia muncul sebagai "sosok yang berkehendak".Dalam metafora permainan sebak bola, Sandi adalah penyerang yang "aktif menjemput bola".

Selanjutnya pengelolaan bunyi vokal Sandi atau paralangue.Pengendalian Sandi terhadp kualitas suara dalam penjelasnnya sangat baik.Hal ini ditunjukkan melaluikecepatan dan intonasi suara yang tidak terlalu tinggi dan tidak terlalu rendah.Kontrol nada suara tersebut menandakan karakter Sandi yang tenang. Pemaknaan ini sekaligus menyisakan mitos bahwa ke depan, jika terpilih menjadi wakil Gubernur Jakarta, Sandi tidak akan mengeluarkan kebijakan dengan ketergesa-gesaan, melainkan penuh pertimbangan dan "hati yang dingin".

Pada level interpretasi yang lebih tinggi, hal ini bisa bermakna "kritik" pada rezim penguasa hari ini yang oleh sebagian pengamat politik dituding sebagai 
“rezim panik". Kajian dengan ruang lingkup politik nasional akan dibahas dalam kesempatan yang lain.

Aspek non-verbal terakhir adalah ekspresdi wajah dan kontak mata. Secara umum Sandi sebagai komunikator yang berbicara kepada komunikanbaik lawan debat maupun khalayak yang hadir menonton berhasil memamfaatkan kontak mata yang baik. Pada banyak kesempatan Sandi mengarahkan pandangan matanya pada khalayak diberbagai sudut sambil menjelaskan pendapatnya.Begitupun saat bertanya kepada lawan debatnya, Sandi selalu menjaga kontak mata.Berbicara sambil menunujukkan senyuman adalah penanda kuat bahwa seseorang itu ramah dan santun.

Serupa dengan pasangannya Anies Baswedan, pesan konotatif dibalik senyuman ramah Sandi disertai pandangan yang santun seolah menegaskan posisi paslon ini sebagai antitesa dari lawan politiknya yang terkenal berapi-api dan "mudah marah". Positioning ini menjadi penting untuk ditanamkan dalam persepsi kolektif khalayak di tengah masyarakat yang gandrung dengan komentarkomentar tengtang personality para politisi.

Pada akhirnya pesan verbal non-verbal yang ditandakan oleh Sandiaga Uno mencitrakan bahwa dirinya adalah calon pemimpin inovatif yang ahli di bidang manajemen keuangan (ekonom) dan ahli pembangunan.Jejak rekan kinerja Sandi dalam dunia usaha adalah "pendongkrak" kredibilitas yang efektif. Dibanding dengan positioning tiga kandidat lainnya, Sandi adalah orator yang baik sekaligus tipikal pekerja yang ulet.

\section{Penutup}

\section{Kesimpulan}

Debat Kandidat Pilkada Jakarta sebagai panggung pencitraan menjadi strategis bagi kandidat untuk membangun positioning di benak khalayak. Dari hasil penelusuran semiotis, baik verbal dan nonverbal, berikut adalah kesimpulan dari penelitian ini:

\section{Positioning Isu Politik Pasangan Calon}


1. Ahok-Djarot mengusung Visi Jakarta Modern. Sedangkan Anies-Sandi mengusung Visi Jakarta Maju.Singkat kata "modern vs. maju”.

2. Ahok-Djarot diuntungkan dalam pemaparan program kerja dikarenakan telah mengerjakan sebahagian program tersebut selama menjabat sehingga mampu menyerang program Anies-Sandi yang dicap masih sebatas janji. Di sisi lain, Anies-Sandi diuntungkan karena mampu mengkritik program Ahok-Djarot yang belum terealisasi dan tidak pro rakyat kecil melalui pertanyaan-pertanyaan seputar pulau reklamasi dan penggusuran.Status quo vs. perubahan.

3. Kebijakan program Ahok-Djarot lebih bersifat top-down yang mana pemerintah melalui pertimbangan pakar dan perwakilan masyarakat merumuskan program kemudian meminta masyarakat untuk berperan aktif dalam eksekusinya. Sementara kebijakan program Anies-Sandi lebih bersifat bottom-up, dimana pemerintah melibatkan masyarakat luas sejak awal perumusan program hingga eksekusinya.Top-down vs bottom -up.

\section{Positioning Citra Pribadi Kandidat}

1. Basuki Tcahaya Purnama (Ahok) adalah pekerja yang ulet dan tegas tapi bukanlah orator yang baik

2. Djarot Saiful Hidayat adalah pekerja yang ulet dan birokratis tapi bukanglah orator yang baik

3. Anis Rasyid Baswedan adalah orator yang baik dan santun tapi bukanlah pekerja yang ulet

4. Sandiaga Salahudin Uno adalah pekerja yang ulet dan kreatif sekaligus orator yang baik

\section{Positioning Citra Pasangan Calon}

1. Ahok-Djarot mencitrakan diri mereka sebagai pemimpin yang tegas dan lugas dalam mengeksekusi kebijakan-kebijakan pemerintah. Sedangkan Anies-Sandi mencitrakan diri sebagai pemimpin yang santun dan 
mengayomi masyarakat dalam melaksanakan kebijakan-kebijakan yang berpihak pada rakyat.Administratif vs. humanis-inklusif.

2. Ahok-Djarot mencitrakan diri mereka sebagai pemimpim yang berpengalaman di bidang pemerintahan sedaangkan Anies-Sandi mencitrakan diri mereka sebagai pemimpin yang pro rakyat dengan menolak reklamasi dan relokasi melalui penggusuran. Hal ini sekaligus menjadi argumen untuk menyerang kebijakan dan program kerja lawannya.

3. Terkahir, Ahok-Djarot adalah kempempinan yang dekat dengan sekulerisme sedangan Anis-Sandi adalah kepemimpinan yang dengan dengan religiusisme.

\section{Daftar Pustaka}

Adityawan, Arief. 2008. Propaganda Pemimpin Politik Orde Baru. Jakarta: LP3ES.

Barthes, Roland. 2013. Mitologi (Edisi Revisi). Nurhadi, A. Sihabul Millah (terj). Bantul: Kreasi Wacana.

Bungin, Burhan. 2007. Penelitian Kualitatif: Komunikasi, Ekonomi, Kebijakan Publik, dan Ilmu Sosial Lainnya (Cetakan Kelima). Jakarta; Kencana, Pranada Media Groub.

B.W. Head. 2012 . Ideology and Social Science. New York: Springer Science \& Bisiness Media. 2012.

Cangara, Hafied. 2014. Komunikasi Politik (Edisi Revisi). Jakarta: PT. Raja Grafindo Persada.

Firmanzah. 2008. Marketing Politik; Antara Pemahaman dan Realitas. Jakarta: Yayasan Obor Indonesia.

------. 2011. Mengelola Partai Politik: Komunikasi dan Positioning Ideologi Politik di Era Demokrasi (Edisi Kedua). Jakarta: yayasan Obor Indonesia.Kaid, Lynda L (ed). 2004. Handbook of Political Communication Research. London: Lawrence Erlbaum Associates.

Tarigan, Hendry Guntur.2009.Pengajaran Semantic, Bandung:Angkasa

Kaid, Lynda L (ed). 2004. Handbook of Political Communication Research. London: Lawrence Erlbaum Associates. 
Kotler, Philip and Eduardo L. Roberto. 1989. Social Marketing; Strategies for Changing Behaviour. New York: The Free Pass.

Metz, Christian. 1974. Film Language: A Semiotic of the Cinema; Translated by Michael Taylor. New York: Oxford University Press.

McQuail, Denis. 1987. Teori Komunikasi Massa. Penerjemah Agus Dharma dan Aminuddin Ram. 1989. Jakarta: Erlangga.

Nastini, Mahanti Sari. 2012. "Analisis Semiotik Video Jokowi-Ahok Di YouTube Dalam Masa Kampanye Pemilihan Gubernur DKI Jakarta 2012. ’Jakarta

Nimmo, Dan. 2004. Political Communication and Public Opinio in America. Alih Bahasa, Tjun Suharman "Komunikasi Politik, Komunikator, Pesan, dan Media.” Bandung: PT Remaja Rosdakarya Offset.

Piliang, Yasraf Amir. 1998. Sebuah Dunia Yang Dilipat:Realitas Kebudayaan MIlenium Ketiga dan Matinya Posmodernisme. Bandung: Mizan.

------1999. Hiper-realitas Kebudayaan. Lembaga Kajia Islam dan Sosial.

Rice, Ronald E and William J. Paisley (ed). 1981. Public Communication Campaigns. Baverly Hills - London: Sage Publication.

Ries, A., \& Trout, J. (1981).Positioning The Battle of Your Mind.New York: McGraw-Hill.

Sobur, Alex. 2013. Semiotika Komunikasi (Cetakan Kelima). Bandung: Rosdakarya.

Suseno, Franz - Magnis. 1992. Filasafat Kebudayaan Politik: Butir-Butir Pemikiran Kritis. Jakarta; Gramedia Pustaka Utama.

Swanson, David L and Dan Nimmo (ed). 1990. New Direction in Political Communication; A Resource Book. London: Sage Publication.

Tinarbuko, Sumbo. 2013. Semiotika Komunikasi Visual. Yogyakarta: Jalasutra.

West.R \& Turner. Lynn H. 2008. Pengantar Teori Komunikass;Anlisis dan Aplikasi. Jakarta: Salemba Humanika.

Wibowo, Indiwan Seto Wahyu. 2011. Semiotika Komunikasi: Aplikasi Praktis Bagi Penelitian dan Skripsi Komunikasi. Jakarta: Mitra Wacana Media.

Djunaisih S. Sunarjo, Komunkasi, Persuasi Dan Retorika (Yogyakarta: Liberty, 1983). 
Jalaluddin Rahmat, Retorika Modern (Bandung :Remaja Rosda Karya, 2001), https://profil.merdeka.com/indonesia/b/basuki-tjahaja-purnama/ https://profil.merdeka.com/indonesia/d/djarot-saiful-hidayat/ https://profil.merdeka.com/indonesia/a/anies-baswedan/ https://www.merdeka.com/tag/s/sandiaga-uno/ http://www.antaranews.com/berita/595154/makna-seragam-kampanye-kotakkotak-ahok-djarot 